\title{
Personal Income Tax Reform: Concepts, Issues, and Comparative Country Developments
}

Howell H. Zee 


\title{
IMF Working Paper
}

Fiscal Affairs Department

Personal Income Tax Reform: Concepts, Issues, and Comparative Country Developments Prepared by Howell H. Zee ${ }^{1}$

April 2005

\begin{abstract}
This Working Paper should not be reported as representing the views of the IMF. The views expressed in this Working Paper are those of the author(s) and do not necessarily represent those of the IMF or IMF policy. Working Papers describe research in progress by the author(s) and are
\end{abstract} published to elicit comments and to further debate.

This paper provides a largely nontechnical survey of concepts and issues related to the reform of the personal income tax, covering both base and rate aspects of the tax, as well as fundamental reform options. It also covers recent developments in selected OECD countries.

JEL Classification Numbers: H20, H24

Keywords: Tax reform, personal income tax

Author(s) E-Mail Address: hzee@imf.org

\footnotetext{
${ }^{1}$ Helpful comments from Reed Shuldiner and Emil Sunley are gratefully acknowledged. The usual disclaimer applies.
} 


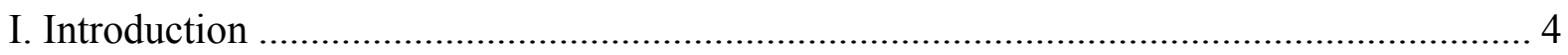

II. Foundational Issues in Taxing Personal Income ....................................................

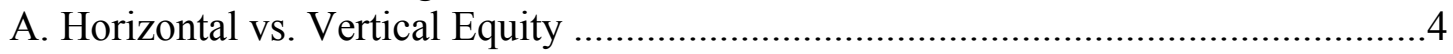

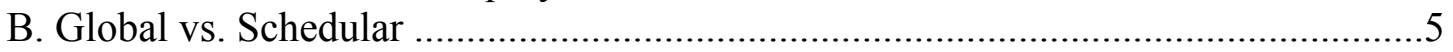

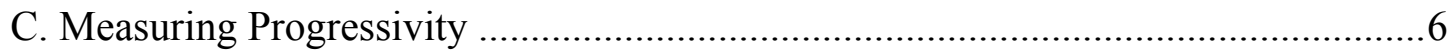

D. Efficiency Implications: Impact on Labor Supply and Savings ........................... 9

E. Equity Implications: Impact on Progressivity and Income Distribution ................ 10

F. Social Welfare and Optimal Shape of the PIT Rate Schedule ............................ 14

III. Design of the PIT: Rate Schedule .......................................................................... 15

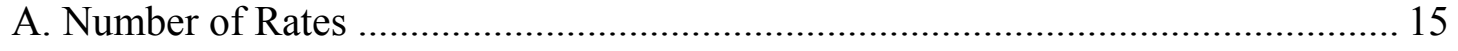

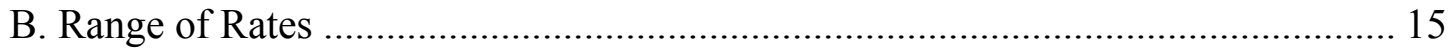

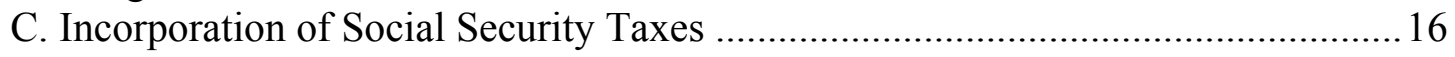

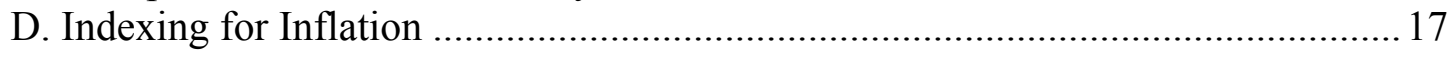

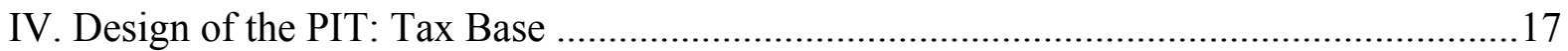

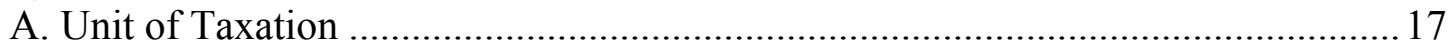

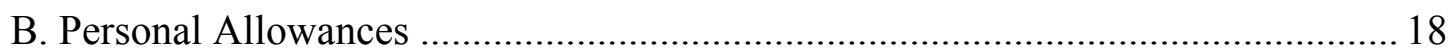

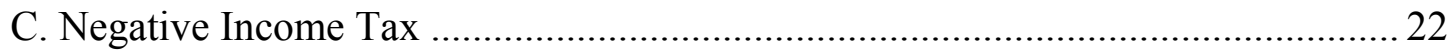

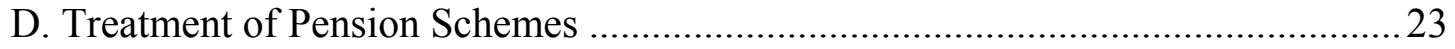

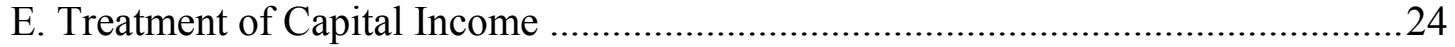

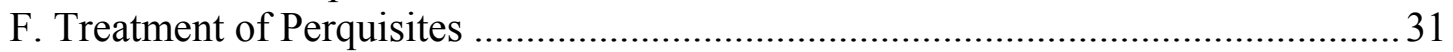

G. Treatment of the Self-Employed .................................................................. 32

H. Residence Rules and Foreign Tax Credits ....................................................... 32

V. Design of the PIT: Intergovernmental Dimension .............................................. 33

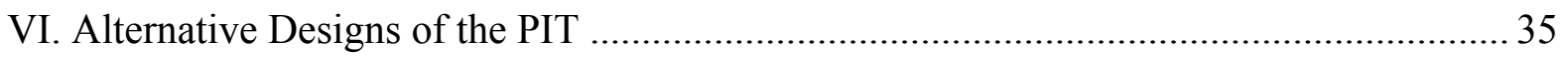

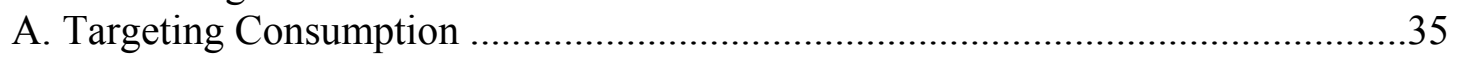

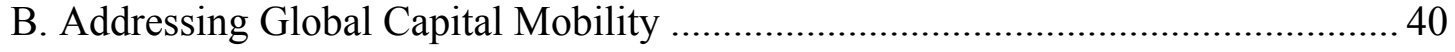

VII. PITs in Selected OECD Countries ...................................................................... 42

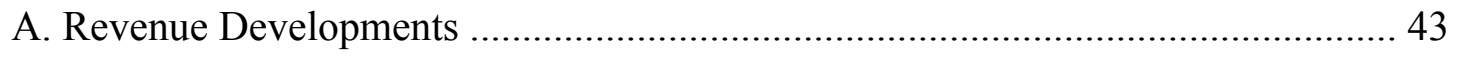

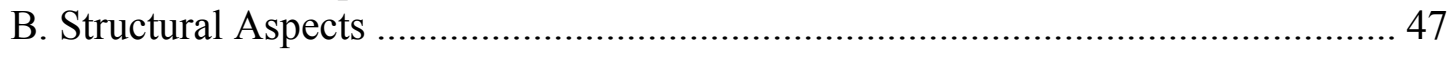

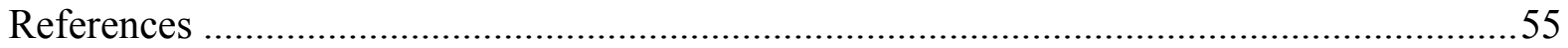




\section{Tables}

1. Comparative Features of the Income Tax Systems in the Nordic Countries, 2002............41

2. Selected OECD Countries: PIT Revenue, 1986-2002 .................................................... 44

3. Selected OECD Countries: PIT Revenue by Level of Government, 2000 ....................... 45

4. Selected OECD Countries: Structure of Tax Revenue, 1986-2002 …............................46

5. Selected OECD Countries: PIT Rate Structure and Basic Allowance, 1986 and 2002 ..... 48

6. Selected OECD Countries: Aggregate Maximum Marginal Tax Burden on Wages, 2002.49

7. Selected OECD Countries: PIT Treatment of Capital Income, 2002 ................................ 51

8. Selected OECD Countries: Aspects of the PIT Base, 2002 .............................................54

Figures

1. Lorenz and Tax Liability Concentration Curves .................................................... 12

2. Equivalence Between a Deduction and a Tax Credit ................................................. 21 


\section{INTRODUCTION}

This paper provides a concise survey of a number of theoretical and practical aspects of designing a personal income tax (PIT). It is intended to be neither comprehensive in its coverage of topics nor rigorous in its analytical treatment of the topics covered. Rather, its purpose is to inform policymakers of the most relevant concepts, issues, and comparative country developments when they are contemplating PIT reform. To maximize its accessibility to policymakers, the survey is largely nontechnical.

The survey begins with a brief overview of some foundational issues in taxing personal income (Section II), followed by a discussion of the different design aspects of the PIT: the rate schedule (Section III); the base (Section IV); the intergovernmental dimension (Section $\mathrm{V}$ ); and targeting consumption as well as addressing concerns about global capital mobility (Section VI). It concludes with a comparative description of PIT developments in selected OECD countries (Section VII).

\section{Foundational Issues in Taxing Personal Income}

Each of the following foundational issues has a voluminous literature that raises either philosophically complex or technically demanding questions, or both. An in-depth treatment of such issues is, therefore, well beyond the scope of the present paper. The cited references provide gateways to the relevant literatures.

\section{A. Horizontal vs. Vertical Equity}

Equity concerns are often at the forefront of policy deliberations on the design of a PIT. It is common to express these concerns in terms of the following two widely-used concepts of equity: (1) horizontal equity (HE) — the equal tax treatment of equals; and (2) vertical equity (VE) - the unequal tax treatment of unequals. Both concepts are consistent with the abilityto-pay principle of taxation — one of two fundamental tax principles. ${ }^{2}$

Stated in general terms, few can disagree with either of the above two equity concepts: HE is generally seen as a rule to ensure fairness of a tax system, while VE as one to achieve distributive justice. Difficulties arise, however, when they have to be given operational contents. For HE, there are questions about both the definition of "equals" (e.g., equality of income or welfare, endowment or outcome, at a given point in time or over the life cycle) and the specification of "equal tax treatment" (e.g., equality in absolute tax payments or in tax payments relative to income). For VE, how unequal should unequals be treated is clearly a question of value judgment. On this, notions of distributive justice could range between two extremes: utilitarian (social welfare is the sum of individual welfare) and Rawlsian (social welfare is the welfare of the least well-off) — each giving rise to a different view on the extent

\footnotetext{
${ }^{2}$ The other fundamental tax principle is the benefit principle, which says that people should be taxed according to the benefit they receive from the government services financed by the tax revenue raised. The benefit principle is not, however, relevant for the discussion of a general broad-based tax such as the PIT.
} 
of unequal tax treatment of unequals, and hence different implications for PIT design, such as its degree of progressivity. ${ }^{3}$

The disentangling of HE and VE effects of a PIT is a subject of some lively debate in the literature. To see the issues involved, note that the tax transforms any given pretax income distribution into a different, post-tax income distribution. If people with the same level of pretax income end up with different levels of post-tax income, then HE would be violated. According to one strand of the literature, the extent of this violation could be measured in the following way. First, compute the average of the post-tax income of all people with the same pretax income for each level of pretax income, thus producing a (hypothetical) distribution of average post-tax income. Then, on the basis of some social welfare function, compute the difference between the social welfare associated with the actual post-tax distribution and that associated with the hypothetical distribution. This difference would then be a measure of the degree of horizontal inequity. As regards the degree of vertical inequity, it would be measured by the difference in social welfare between the hypothetical distribution and some given distribution that is deemed to be socially optimal. ${ }^{4}$

A second strand of literature argues that the measurement of horizontal inequity above ignores the fact that the rank order (along the income scale) of individuals could be altered during the transformation of the pretax to a post-tax distribution of income. Such a re-ranking is considered an attribute of horizontal inequity. To take its impact into account, the construction of the hypothetical distribution of average post-tax income should be mapped so that the original (pretax) rank order is preserved. This rank-preserving hypothetical distribution could then be used to decompose, as before, the HE and VE effects of the tax. ${ }^{5}$

\section{B. Global vs. Schedular}

Another foundational issue to be confronted at the outset in designing a PIT is whether a single rate schedule should apply to the aggregate of different sources of income (the global income approach), or different rate schedules should apply to different sources of income (the schedular approach). This issue is of fundamental importance, as it would determine, among other things, whether labor and capital income should be taxed separately — and differently.

\footnotetext{
${ }^{3}$ The theoretical construct that gives expression to a particular notion of distributive justice is commonly referred to as a social welfare function. It is possible to write such a function in a way to encompass the spectrum of different notions of distributive justice bracketed by the utilitarian and Rawlsian extremes by varying a single parameter of the function. See Zee (1995) for elaborations of these issues.

${ }^{4}$ See Musgrave (1990) for a modern restatement of this classical strand of the literature.

${ }^{5}$ The seminal contribution to the re-ranking literature is Atkinson (1980). Feldstein (1976) has argued for the use of no re-ranking as one of the conditions for implementing tax reforms.
} 
Until recently, the global income approach, underpinned by the classic works of Haig and Simons, ${ }^{6}$ dominated the thinking of the economics profession (although in reality few PITs, if any, can be regarded as truly global in nature). It is also an approach that would follow logically from the HE dictum, as the taxable capacity of an individual (i.e., the attribute by which equals may be defined under the PIT) is determined by the totality of income irrespective of the sources from which it is derived.

However, in view of the unprecedented degree of global capital mobility that has been observed over the last decade and a half - a trend that can only be expected to further accelerate in the future, a fundamental rethinking in the profession about the advisability of adopting the global income approach can now be clearly detected. It is increasingly recognized and accepted, for example, that the benefit from adhering to HE should be weighed against the considerable difference in mobility between labor and capital. Indeed, the reality of the difficulties in taxing a highly mobile tax base-without resorting to harmful quantitative controls - has already induced a number of countries to explicitly forsake $\mathrm{HE}$ and pursue differential (schedular) taxation of labor and capital income, with the latter bearing a much lighter tax burden (see further discussion in Section VI below). Hence, the attractiveness of the global income approach to taxing income seems to be fading unmistakably in a globalized world. ${ }^{7}$

\section{Measuring Progressivity}

While HE is an important consideration in the global-schedular debate, VE is the central concern when deciding how progressive the PIT should be. There are a number of different ways to measure the degree of progressivity of a tax. Before discussing the significance of these measures, however, it would be necessary to define more precisely what is meant by a progressive tax.

Consider a tax, $t$, that varies with the level of pretax income, $y$. $t$ is, therefore, a function of $y$, denoted by $t(y)$. The marginal tax rate at a given $y$, denoted by $m(y)$, measures how the tax would change in response to a one-unit change in pretax income at that given pretax income level. In other words,

$m(y)=\Delta t(y) / \Delta y$ at some given $y$

where $\Delta$ is a symbol representing the change in a variable. We assume for simplicity in the present discussion that the marginal tax rate is always nonnegative and less than unity, that is, $1>m(y) \geqslant 0$. The average tax rate at a given $y$, denoted by $a(y)$, is simply the ratio of the tax to pretax income at that given pretax income level:

$a(y)=t(y) / y$ at some given $y$,

\footnotetext{
${ }^{6}$ An eloquent modern articulation of the Haig-Simons global income approach is given by Goode (1975).

${ }^{7}$ See Zee (2002) for an extended discussion of taxing capital income in a globalized world.
} 
which is also assumed to be always nonnegative and less than unity, that is, $1>a(y) \geqslant 0$. A tax is said to be globally progressive if its average tax rate rises with pretax income over the entire income range, that is,

$\Delta a(y) / \Delta y>0$ for all $y$.

Given equations (1) and (2), condition (3) can be equivalently stated as: ${ }^{8}$

$m(y)>a(y)$ for all $y$.

Condition (4) is fairly intuitive: the only way the average tax rate can rise with pretax income - to satisfy the definition of progressivity as stated in condition (3) - is to have the rate at which the tax increases with rising pretax income, i.e., the marginal tax rate, be greater than the average tax rate itself. In contrast, a tax would be proportional if $m(y)=a(y)$, and regressive if $m(y)<a(y)$.

Having a definition of progressivity alone is not sufficient to enable one to compare the relative progressivities of different taxes. For that, a measure of the tax progression, or the degree of progressivity, would be needed. Four prominent progression measures have been used in the literature: ${ }^{9}$ marginal, average, liability, and residual.

\section{Marginal progression}

The marginal progression (MP) measure compares the relative progressivities of different taxes at a given pretax income level by the way their marginal tax rates change with respect to a change in pretax income at that pretax income level. Thus, this measure requires the calculation of:

$\mathrm{MP}=\Delta m(y) / \Delta y$ at some given $y$.

The higher the MP, the more progressive is the tax. This measure conforms most closely to the common notion of tax progressivity: one tax is considered more progressive than another if the former's marginal tax rates rise more steeply with pretax income than the latter's. ${ }^{10}$

\footnotetext{
${ }^{8}$ The derivation requires the use of calculus by differentiating $a(y)$ with respect to $y$.

${ }^{9}$ These measures were originally developed by Musgrave and Thin (1948).

${ }^{10}$ While it is common to think of MP as being positive, i.e., the marginal tax rate rises with pretax income, this condition is not always observed in effective terms in actual PITs.
} 


\section{Average progression}

Quite analogous to the MP measure, the average progression (AP) measure compares the relative progressivities of different taxes at a given pretax income level by the way their average tax rates change with respect to a change in pretax income at that pretax income level. That is,

$\mathrm{AP}=\Delta a(y) / \Delta y=[m(y)-a(y)] / y$ at some given $y$.

By condition (4), AP is always positive. ${ }^{11}$ The higher the AP, the more progressive is the tax.

\section{Liability progression}

The liability progression (LP) measure looks at the elasticity of the tax liability with respect to pretax income, i.e., the proportional change in the former with respect to a proportional change in the latter, at a given pretax income level:

$\mathrm{LP}=[\Delta t(y) / t(y)] /[\Delta y / y]=m(y) / a(y)$ at some given $y$.

By condition (4), LP is always greater than unity. The higher the LP, the more progressive is the tax.

\section{Residual progression}

The residual progression (RP) measure, in contrast, looks at the elasticity of post-tax income with respect to pretax income at a given pretax income level. Since post-tax income is, by definition, $[y-t(y)]$,

$\mathrm{RP}=\{\Delta[y-t(y)] /[y-t(y)]\} /[\Delta y / y]=[1-m(y)] /[1-a(y)]$ at some given $y$.

By condition (4), RP is always less than unity. The lower the RP, the more progressive is the tax.

\section{Discussion}

When comparing the relative progressivities of different taxes, the alternative progression measures discussed above do not always provide identical results. The question naturally arises as to which of the four measures should in some sense be preferred. In pondering this question, one is led to ask what desirable properties a good progression measure should possess. One possibly appealing property could well be a sort of invariance characteristic: the magnitude of the measured progressivity should not be affected if the tax liability of every

\footnotetext{
${ }^{11}$ The derivation of the second equality in equation (6) requires the use of calculus.
} 
individual is increased or decreased in the same proportion. The LP is the only measure among the four that satisfies this property. ${ }^{12}$

It should also be noted that all of the above progression measures are local measures, in the sense that each provides a measure of the degree of tax progressivity at a given level of pretax income; none provides an index of the global degree of progressivity of a tax. This point is taken up further below on the PIT's impact on income distribution.

\section{Efficiency Implications: Impact on Labor Supply and Savings}

A PIT, like any other tax, will inevitably affect the behavior of individuals. If the PIT taxes both labor and capital income, then the primary behavioral impact of interest would be on labor supply and savings decisions. How these decisions would be distorted by the PIT is, therefore, a central consideration in determining both the shape of its rate schedule and the structure of its base.

In discussing the above PIT distortions, care should be taken to separate two related but different issues: (1) the observed tax-induced changes in the behavior of interest (i.e., the amount of labor supplied and income saved); and (2) the efficiency costs associated with the tax-induced behavioral changes. The efficiency costs may well be significant even if the relevant behavioral changes are observed to be small. To see how this could come about, it would be necessary to understand the income and substitution effects of the PIT. These effects are discussed below with respect to labor supply and savings decisions separately.

\section{Labor supply}

All PITs subject labor income to tax, and in so doing reduce the after-tax wage rate. Obviously, the consequent impact on the wage earner's decision to work would hinge on his wage elasticity of labor supply. Because most empirical studies have shown that this elasticity is extremely low for prime-age male workers as a group, many have taken such evidence to mean that the efficiency cost associated with the impact of the PIT on labor supply is small, or, at the very least, is limited to its impact on secondary workers and, therefore, cannot be very significant for the economy as a whole. However, such a conclusion needs to be carefully qualified because there are two opposing effects of the tax at work here.

First, by making work less rewarding, the tax tends to reduce the wage earner's incentive to work, or, equivalently, induce him to consume more leisure (the substitution effect). At the same time, the tax may make him feel poorer, and thus inducing him to work more (the income effect). The two effects may cancel each other out in reality, thus resulting in the low observed wage elasticity of labor supply of prime-age male workers. But this decidedly does not imply that the substitution effect - the effect by which the efficiency cost of the tax

\footnotetext{
${ }^{12}$ See Kakwani (1980) for a detailed discussion and a demonstration of conflicting comparative results that can be produced by the different measures.
} 
should be measured - is necessarily small by itself. Indeed, recent evidence suggests that it could well be large, thus entailing a significant efficiency cost. ${ }^{13}$

\section{Savings}

If a PIT subjects capital income (i.e., interest, dividends, capital gains, etc.) to tax, it would reduce the after-tax rate of return on savings. The extent to which savings would be affected by the tax would thus depend, as usual, on the interest elasticity of savings. Unfortunately, empirical estimates of this elasticity have ranged widely from almost zero to a relatively high value, rendering doubt as to where the true value may lie. ${ }^{14}$

Even if the true interest elasticity of savings is low, it would not necessarily follow that the efficiency cost of taxing capital income would be low. This is because, again, the substitution and income effects of the tax on savings may offset each other. While savings could be reduced by the tax-induced lowering of the after-tax rate of return on savings, the saver is rendered poorer by the tax, and for this reason alone could decide to save more (to provide for the same amount of future consumption). The observed net impact on savings may thus be small, notwithstanding the fact that the substitution effect - and the efficiency cost — of the tax could well be large.

Another important concern about taxing capital income-a concern that is largely absent in taxing labor income - has to do with its efficiency cost in a dynamic sense, as lower savings will translate into lower investment, lower capital accumulation, and ultimately lower economic growth. Moreover, a reduced level of savings, even if small at a given point in time, may well have a significant adverse growth effect through compounding over time. ${ }^{15}$ This concern has given rise to the debate on the relative merits between taxing income and taxing consumption, an issue that is further addressed in Section VI.

\section{E. Equity Implications: Impact on Progressivity and Income Distribution}

While the above discussion on the efficiency implications of the PIT points to keeping both its rate level and progression low to minimize efficiency costs, this may well have to be weighed against the policymaker's VE (i.e., distributive) concerns, which, as already noted, are also central to the PIT design. The fundamental questions of policy interest here are two: (1) ascertaining whether one PIT would reduce income inequality more than another at all pretax income levels; and (2) identifying gainers and losers from reforming the PIT. These two questions are related but not identical: the first relates to comparing relative global

\footnotetext{
${ }^{13}$ For a detailed discussion of such findings, see Hausman (1985).

${ }^{14}$ An often-cited study that found a high interest elasticity of savings was by Boskin (1978); one that found a low elasticity was by Blinder (1975). Reviewing the empirical evidence, Auerbach and Slemrod (1997) recently argued that the elasticity is probably close to zero. Tanzi and Zee (2000) provide recent statistically significant evidence on the impact of taxes on household savings behavior in a large sample of OECD countries.

${ }^{15}$ See Summers (1981) for a well-known study on the dynamic effects of taxing capital income.
} 
progressivities of different PITs, while the second their explicit redistributive effects among different income groups. The difference between the two lies in the fact that, though all progressive taxes have a implicit redistributive effect, in the sense that the post-tax income distribution would be less unequal than the pretax income distribution, a PIT reform may well have the explicit objective of benefiting some income groups at the expense of others.

\section{Global tax progressivity}

The various measures of tax progressivity discussed earlier, being local measures at given pretax income levels, cannot provide an answer to the above question. What is needed, instead, is an index of global progressivity covering the entire pretax income scale.

One prominent global progressivity index is known as the Kakwani index, $K$, which involves the use of the so-called concentration curve for tax liability. ${ }^{16}$ As in well known, the (pretax) Lorenz curve depicts the relationship between two variables: the cumulative share of (pretax) income on the vertical axis (ranging from zero to unity) and the cumulative proportion of individuals receiving the (pretax) income on the horizontal axis (ranging also from zero to unity). Thus, if (pretax) income were perfectly equally distributed, the Lorenz curve would coincide with the 45 degree ray from the origin (the diagonal line); otherwise, it would always lie below the diagonal line. A typical Lorenz curve is shown in Figure 1 as the curve $L$. It is also well known that the Gini coefficient, $G$, which is one of the most widely-used indices of income inequality, is related to the Lorenz curve as the ratio of the area between the diagonal line and the Lorenz curve $(\operatorname{area} X)$ to the area below the diagonal line (area $X+$ $Y+Z$ ), or

$G=X /(X+Y+Z)=1-2 \cdot(Y+Z)$.

$G$, therefore, varies between zero (complete equality) and unity (maximum inequality).

The concentration curve for tax liability is a construct similar to the Lorenz curve, except that the variable on the vertical axis is now the cumulative share of tax liability. An example of this curve is also shown in Figure 1 as the curve $T$. Analogous to the Gini coefficient, a concentration coefficient of tax liability, $N$, can be derived as one minus twice the area under the concentration curve for tax liability, that is,

$N=1-2 \cdot Z$

It is clear that $N$ also varies from zero (maximum tax regressivity - the $T$ curve coincides with the diagonal line) and unity (maximum tax progressivity).

The Kakwani index is then defined as

$K=N-G=2 \cdot Y$

\footnotetext{
${ }^{16}$ For details of derivation, see Kakwani (1977).
} 
Figure 1. Lorenz and Tax Liability Concentration Curves

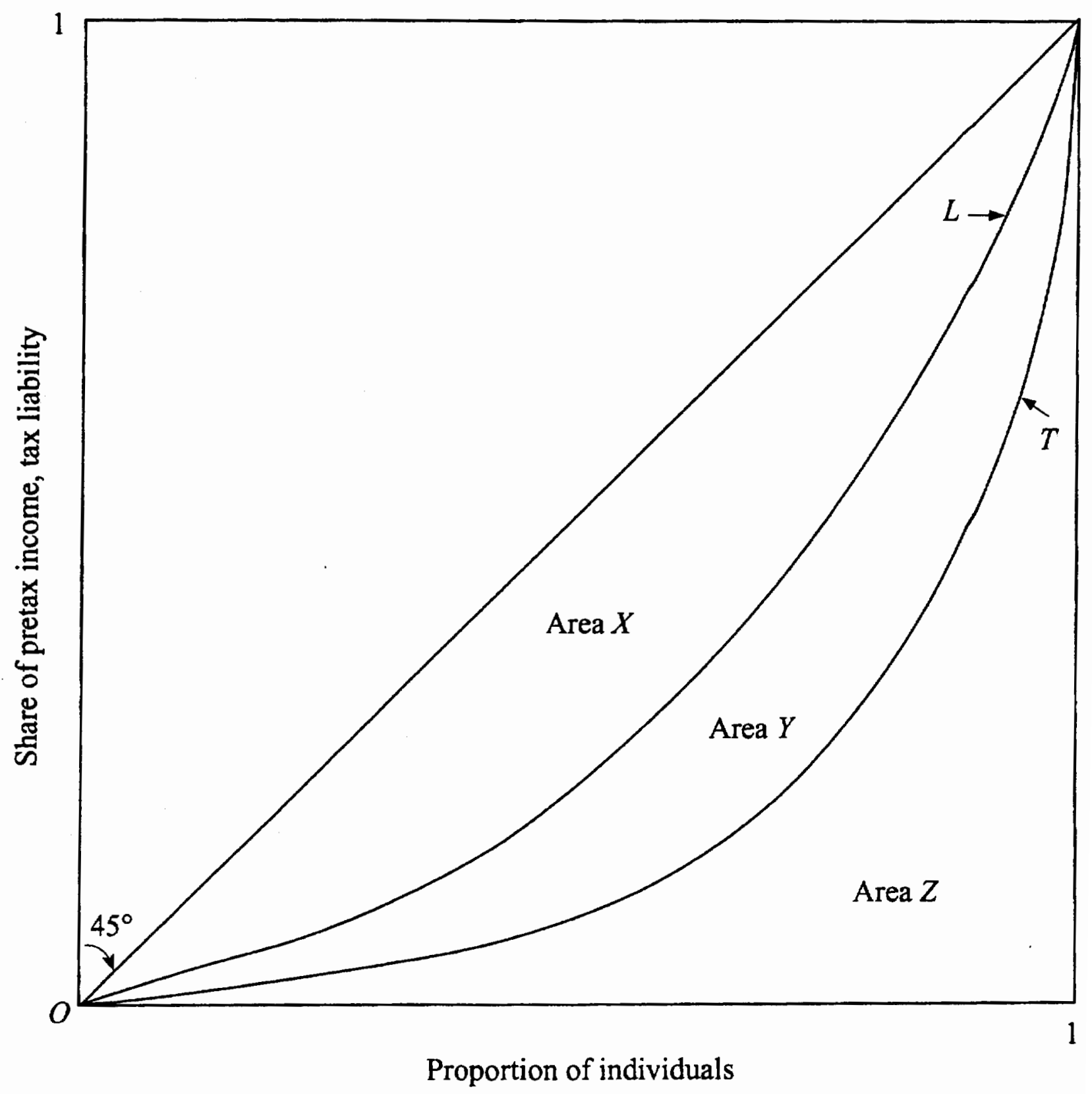


which is twice the area between the Lorenz curve and the tax liability concentration curve. The higher the $K$, the more globally progressive is the tax. For a given $G$, the value of $K$ varies from $(-G)$ to $(1-G)$, a negative $K$ being an indication that the tax is regressive. The $T$ curve would coincide with the $L$ curve (i.e., $K=0$ ) if the tax is proportional.

There are two important relationships among $K$, the earlier definition of a globally progressive tax, and the LP measure of tax progressivity at the local level. First, the tax liability concentration curve would lie entirely below (above) the Lorenz curve if the tax is globally progressive (regressive) as defined by condition (4). This is intuitively obvious, since such a progressive (regressive) tax would necessarily give rise to a distribution of tax burden that is more (less) unequal than the distribution of pretax income. Second, given two taxes, $A$ and $B$, and their respective tax liability concentration curves, $T^{A}$ and $T^{B}, T^{A}$ would lie entirely below (above) $T^{B}$ if $\mathrm{LP}^{A}$ is greater (less) than $\mathrm{LP}^{B}$ at all pretax income levels. In this case, it is clear that tax $A$ is more (less) progressive globally than tax $B$, as the Kakwani index associated with $A$ would be higher (lower) than that associated with $B$.

In real world comparisons, however, the tax liability concentration curves for any two given taxes may well cross each other (or, equivalently, the relative magnitudes of their LP measures get reversed) at some pretax income level(s). Under such circumstances, the relative global progressivity of the two taxes is no longer readily ascertainable by comparing the positions of their tax liability concentration curves or the magnitudes of their LP measures. Nevertheless, the Kakwani index for each tax can still be computed and compared to produce an unique answer to the question regarding which tax is more globally progressive.

\section{Explicit redistribution}

If a PIT reform involves an explicit redistributive objective, so that there will be gainers and losers from the reform, then one could be considering alternative PIT rate schedules that cross each other. For example, a revenue-neutral reform that lowers the tax rates on the poor and raises the tax rates on the rich would entail a single crossing of two rate schedules, while replacing a progressive rate schedule with a flat tax could entail a double crossing, as income groups at both the high and low ends of the income scale may benefit at the expense of the middle income group.

The case of the single crossing of two rate schedules has generated much interest in the literature, because it turns out that if one rate schedule is observed to cross another rate schedule only once from below, then it would be possible to conclude that the LP associated with the first schedule is higher than that associated with the second schedule at all pretax income levels, i.e., the first schedule is globally more progressive than the second. The power of this result lies in the fact that an inference about the relative global progressivity of two rate schedules can be made simply from an observed single crossing between them, ${ }^{17}$ even in the absence of reliable income distribution data.

\footnotetext{
${ }^{17}$ This statement is strictly true for revenue-neutral tax reforms. For reforms that are not designed to yield the same tax revenue, the single-crossing result would remain valid if the two rate schedules are "normalized" by
} 
There are also interesting results associated with PIT reforms involving the double crossing of rate schedules of the type noted earlier. It can be shown that such reforms could be deemed desirable across a wide range of different notions of distributive justice. ${ }^{18}$

\section{F. Social Welfare and Optimal Shape of the PIT Rate Schedule}

The tradeoff between efficiency and vertical equity considerations is, of course, the most fundamental policy issue confronting any PIT reform. Broadly speaking, the problem is one of maximizing social welfare - as given by a particular social welfare function that embodies the policymaker's notion of distributive justice - subject to both the behavioral responses of individuals (e.g., how the tax would affect their savings and labor supply decisions) and the economy's technological constraint (e.g., how the supplied capital and labor could be combined to produce income). Whether anything useful can be said about the shape of the PIT rate schedule from solving the above optimization problem has been the subject of a large number of both theoretical and simulation investigations.

Overall, theoretical studies have succeeded in producing only limited insights on the optimal shape of a PIT rate schedule. Based on one-period models where only wages are taxed, the most important results are (provided that certain technical conditions are satisfied): (1) the optimal marginal tax rates are nonnegative and less than unity at all pretax income levels, that is, $1>m(y) \geqslant 0$ (which is exactly what was assumed in earlier discussions); and (2) the optimal marginal tax rates at both ends of the income scale are zero. Theory alone imparts few additional insights, however, about the optimal shape of the rate schedule between the income end points. ${ }^{19}$

In view of the limited insights that can be gleamed from theoretical studies on the optimal rate schedule, researchers have turned to simulations based on specific assumptions about the structure of individual preferences for consumption and leisure, the dispersion of skills (and therefore wages), and the policymaker's notion of distributive justice. As expected, the simulation results tend to be sensitive to model specifications, with findings of both relatively

their respective average tax rates. For details, see Hemming and Keen (1983), who introduced the singlecrossing result into the literature.

${ }^{18}$ See Lambert (2001) for some insightful discussions.

${ }^{19}$ The theoretical literature on the optimal shape of the PIT rate schedule tends to be highly technical, but an accessible and lucid discussion of these results can be found in Tuomala (1990). The result that the optimal marginal tax rates are zero at both end points of the income scale, while striking, is in fact quite intuitive. To quote Tuomala (1990, p. 92), who in turn drew from Seade (1982): “A positive marginal tax rate for any level of gross income increases the tax burden of those people from the given point onwards in the income scale and decrease in turn the tax burden from that point downwards. This explains why the marginal tax rates are zero at both ends of the distribution. In the lowest-income case there are no possible beneficiaries of the tax changes further down the scale, and in the case of the highest income only efficiency arguments prevail." 
flat and progressive optimal rate schedules. ${ }^{20}$ On the whole, these findings provide little practical guidance for determining the level and structure of PIT rates.

\section{DESIGN OF THE PIT: RATE SCHEDULE}

The following discussion assumes that there is only a single rate schedule. In some countries, however, different types of income and/or taxpayers are subject to different rate schedules. When multiple rate schedules exist, tax rules must be carefully specified to prevent - or at least minimize - abuse by taxpayers through, for example, income misclassification or income splitting not provided in the law.

\section{A. Number of Rates}

While there is no scientific basis for determining the optimal number of PIT rates, a multiplicity of such rates is not necessary for rendering the PIT progressive. This can be most dramatically illustrated by considering the case of a single positive rate $(\tau)$, coupled with an exemption threshold $(e)$ below which pretax income $(y)$ is not taxed. ${ }^{21}$ Total tax payment $(t)$ is then

$t=\tau \cdot(y-e)$.

Dividing equation (12) through by $y$ thus yields the average tax rate $a$ :

$a=\tau-e / y$.

With only one positive tax rate, $\tau$ is, of course, also the marginal rate (for income above the exemption threshold). From equation (13), it is cleared that $\tau>a$ as long as $e>0$, which satisfies the definition of progressivity given by condition (4). It is true that the difference between $\tau$ and $a$ is reduced by an increase in $y$, and for this reason a compelling case could perhaps be made for introducing one or two additional higher marginal rates on the well-off to ensure that the degree of progressivity would not fade too rapidly with rising income, should vertical equity be an important concern. Nevertheless, the point remains that an adequate degree of progressivity could usually be delivered by only a few positive rates. Moreover, keeping the number of rates low would also ease administration.

\section{B. Range of Rates}

The possibly significant efficiency costs, as well as evasion risks, of high marginal rates usually argue for setting the top PIT rate at a reasonable level—commonly perceived to be

\footnotetext{
${ }^{20}$ Simulation results based on different model specifications can be found in Diamond (1998), Kanbur and Tuomala (1994), Tuomala (1990), and Zee (2004a).

${ }^{21}$ It is assumed for the time being that $t=0$ when $y<e$. The case where $t<0$ is allowed is discussed in a later section on the negative income tax.
} 
below 50 percent. Another important consideration in setting this rate concerns the differential between the top PIT rate and the corporate income tax (CIT) rate. When the former exceeds the latter, an incentive is created for high-income individuals to incorporate themselves to take advantage of the lower CIT rate. Such behavior has indeed been observed in countries where such an incentive exists and is large enough to overcome the transaction costs of artificial incorporation for tax reasons. Hence, it is generally considered good policy the keep the gap between the two rates to a minimum, unless the tax system is explicitly designed to be of the dual-income type (see Section VI).

The bottom PIT rate could be either zero or some positive rate. A zero rate over an income range would be an alternative way for specifying an exemption threshold - if such a threshold is designed to apply to the same set of taxpayers to whom the rate schedule applies. If an exemption threshold is separately specified, then the choice of the level of the (positive) bottom PIT rate would depend on a number of considerations, including the desired revenue yield and the degree of curvature of the entire rate schedule (which is, in turn, dependent on the desired range and number of rates).

\section{Incorporation of Social Security Taxes}

Social security taxes (SST), which are typically imposed on wages of the employee, or payroll of the employer, or both more commonly, could contribute to a significant increase in the tax burden on personal income and should, therefore, be taken into account when deciding on the PIT rate schedule. To see the interactions between the SST and the PIT, assume for simplicity that there is a single SST rate on the employee, $s_{1}$; a single SST rate on the employer, $s_{2}$; and a single PIT rate, $\tau$.

If $s_{2}$ is deductible against the employer's CIT, as is common, the gross labor cost $(l)$ to the employer would be

$l=1+(1-\delta) \cdot s_{2}$

where $\delta$ is the CIT rate. Similarly, if $s_{l}$ is deductible against the employee's PIT, the net-oftax wages $(w)$ of the employee would be

$w=\left(1-s_{1}\right) \cdot(1-\tau)$

The total effective tax burden on wages is the difference between the gross labor cost to the employer and the net-of-tax wages of the employee, that is,

$l-w=(1-\delta) \cdot s_{2}+(1-\tau) s_{1}+\tau$.

Hence, depending on $s_{1}$ and $s_{2}$, SST could raise the tax burden on wages quite significantly. In some countries, this burden is mitigated somewhat by the application of a ceiling on wages subject to either $s_{1}$ or $s_{2}$ (or both), which primarily benefit, of course, high wage earners. Wage ceilings under the SST are thus regressive. 


\section{Indexing for Inflation}

If the rate bands of the PIT rate schedule stay invariant over time, taxpayers with unchanged real income would find themselves facing higher marginal tax rates as their nominal income rises with inflation, which is clearly an inequitable outcome. In some countries where high inflation is a chronic problem, extensive indexation of the tax system is implemented to minimize inflation-induced tax consequences. One extreme form of indexation (e.g., as practiced in some Latin American countries) could be to specify all nominal quantities in the PIT in some artificial tax units rather than in units of the local currency. The exchange rate between the tax and currency units could then be adjusted in line with changes in a chosen price index (such as the CPI). In a majority of countries with moderate inflation, however, such an indexation scheme is probably unnecessary. Under most circumstances, adjusting the PIT rate bands, as well as some personal allowances (see below), based on changes in the CPI (or even periodically on an ad hoc basis) would be adequate for alleviating much of the undesirable tax impact from inflation. ${ }^{22}$

\section{Design OF The PIT: TAX BASE}

There are many issues to be considered in designing the PIT base, those identified below being some of the more important ones. They are by no means exhaustive.

\section{A. Unit of Taxation}

If the PIT has a single rate, it would be immaterial whether the unit of taxation is the individual or the family. Under a progressive rate structure, however, the chosen unit of taxation could confer substantial benefit or penalty when individuals change their marital status. If the tax unit is the family, for example, whether the total tax liability of two individuals would increase or decrease after marriage would depend on the discrepancy between their individual earnings in conjunction with the extent to which income splitting is allowed under the PIT. ${ }^{23}$ Of course, differences, if any, in personal allowances granted to single individuals and families would also matter.

\footnotetext{
${ }^{22}$ It should be noted that indexing the rate bands and personal allowances will remove "band creep," i.e., being thrown into a higher rate band due to inflation, but not the tax burden on inflation-induced rise in nominal income. Indexing income (such as specifying all nominal quantities in tax units noted above) will remove both, but its higher administrative costs may not justify its implementation in a low-inflation environment.

${ }^{23}$ Income splitting refers to pooling together the earnings of the husband and wife and splitting the resultant total between the two in some given proportion for tax purposes. Full splitting means equal division, and is equivalent to having two PIT rate schedules - every income band of the schedule applicable to married couples being twice as wide as that applicable to single individuals. Hence, income splitting would be effectively incomplete if the width of some income band(s) of the former schedule is less than double that of the latter. With incomplete income splitting, the likelihood of a "marriage penalty" is higher, the smaller is the difference in earnings between the husband and wife. The marriage penalty issue has received quite a bit of attention in the United States, although there is no convincing empirical evidence to suggest that people's decision to marry or divorce is significantly affected by this tax penalty.
} 
On efficiency grounds, there is a rather strong argument that joint filing by husbands and wives with full income splitting - which effectively results in equalizing the marginal PIT rates between the two - is sub-optimal, since their labor supply elasticities are not necessarily the same. ${ }^{24}$ Yet, adopting the individual unit of taxation seems inequitable, since families with the same income could now vary greatly in tax liabilities. Thus, neither alternative emerges as the superior choice on all counts. The trend in country practices in developed countries over the past few decades has been a steady shift towards the individual as the tax unit, so much so that the PITs in the majority of OECD countries are now implemented on this basis (the most notable exception being France). ${ }^{25}$

\section{B. Personal Allowances}

Personal allowances of various kinds can be found in every PIT. While a proliferation of such allowances will surely narrow the tax base and complicate tax administration, it is not always correct to argue, as some are inclined to do, that all such allowances should be eschewed in favor of lower tax rates. Some allowances could serve useful purpose, while others could be expressedly designed for altering certain behavior to achieve possibly compelling social or economic objectives. An assessment of their merits and limitations is ultimately a matter of balancing their costs (in terms of revenue forgone) and benefits (in terms of achieving their stated objectives).

Personal allowances fall broadly into two categories: general (basic) and targeted. There is also the question of whether allowances should be granted as deductions to income or as tax credits: they are equivalent under some circumstances but could entail different equity implications under others.

\section{General (basic) allowance}

A general (basic) allowance - an exclusion of a certain amount of income from tax - is one that is granted to a taxpayer irrespective of his/her behavior or circumstances, economic or otherwise. The usual conceptual justification for this is that there is a threshold of income that in some sense goes to meet subsistence and should, therefore, be tax-free. But there are other useful purposes served by the general allowance. First, as noted earlier, its existence would impart progressivity to even a flat-rate PIT. Second, it could be used as a device to exclude many low-income taxpayers - who are usually overwhelming in numbers but collectively pay little tax - from the tax net, thus significantly easing tax administration. These latter two purposes would seem to argue for a high general allowance, but this should be balanced against its revenue cost, which can often be very high, since it reduces the tax of everyone - not just those who have been left out of the tax net in its wake. ${ }^{26}$

\footnotetext{
${ }^{24}$ For a rigorous demonstration of this argument, see Boskin and Sheshinski (1983).

25 The United States allows a choice between the two alternatives, but the tax structure is such that joint filing is almost always more advantageous to married taxpayers.

${ }^{26}$ The observed level of general allowance varies greatly across countries. In general, the level (relative to a country's per capita income) is higher in developing than in developed countries.
} 
As also noted earlier, the substantive effect of a general allowance can be equivalently delivered by a zero-rate band in the rate schedule. The choice is largely a matter of convenience, given other features of the PIT. For example, if all taxpayers face the same rate schedule but it is desired that different taxpayers for whatever reason should receive different amounts of the general allowance, then granting it in the form of an income exemption would obviate the need to introduce different rate schedules.

\section{Targeted allowances}

Targeted allowances - allowances that are granted only if certain qualifying criteria are met - vary greatly in nature, but generally fall into two broad categories: those whose purpose is to address some vertical equity concerns (e.g., handicap allowance), and those whose objective is to encourage certain activities (e.g., allowance for charitable giving). In reality, of course, a majority of targeted allowances have consequences that straddle both categories, irrespective of their original intentions. For example, a medical expenditure allowance may provide the necessary tax relief for the needy, but it may also encourage other taxpayers to incur unnecessary medical expenses whose burden would be partially borne by the tax system. Allowances for child care, education, and many other activities all have similar characteristics. Hence, selectivity in granting targeted allowances is crucial if PIT revenue is to be safeguarded. Furthermore, moral hazard problems would argue for the imposition of ceilings to most such allowances.

Targeted allowances, especially when numerous, could exact heavy administrative costs on the tax authorities and compliance costs on the taxpayers. To alleviate such costs, a blanket allowance could be granted to taxpayers in lieu of the various targeted allowances for which they qualify but choose not to claim.

\section{Deductions vs. tax credits}

All allowances, whether general or targeted, could be given either as deductions to income, or as credits against the tax liabilities. If the PIT has a single rate $\tau$, it is easy to see that a given deduction $d$ would be equivalent to a tax credit $c$, where $c=\tau \cdot d$. If the PIT has multiple rates, the value of a given $d$, i.e., the amount of tax saving the deduction would confer, would clearly depend on the taxpayer's applicable rate band: the higher the rate band, the more valuable the given deduction. In contrast, the value of a given $c$ would remain the same irrespective of the taxpayer's applicable rate band. This is illustrated below assuming the rate schedule consists of two rates: 10 percent on income of 1,000 and below, and 20 percent on income above 1,000 .

\begin{tabular}{|c|c|c|c|c|}
\hline \multirow{2}{*}{ Income } & \multirow{2}{*}{$\begin{array}{c}\text { Marginal } \\
\text { tax rate } \\
\text { (In percent) }\end{array}$} & No allowance & $\begin{array}{c}\text { Deduction } \\
d=200\end{array}$ & $\begin{array}{c}\text { Tax credit } \\
c=10\end{array}$ \\
\cline { 3 - 5 } & \multicolumn{5}{|c|}{} \\
\hline \multicolumn{5}{|c|}{} \\
\hline 1,000 & 10 & 100 & 80 & 90 \\
\hline 10,000 & 20 & 1,900 & 1,860 & 1,890 \\
\hline
\end{tabular}


The deduction of 200 is seen to worth 20 to a taxpayer with income of 1,000 , but 40 to a taxpayer with income of 10,000. By comparison, the tax credit of 10 is worth exactly 10 to all taxpayers irrespective of the income level. Hence, for a given tax schedule with rising marginal rates, replacing a deduction with a tax credit would enhance the vertical equity of the PIT, as well as reduce the revenue cost of the allowance.

It is possible, however, to reproduce the outcome of a deduction with a tax credit by modifying the rate schedule. The modification involves inserting a new first rate band that is equal in size to deduction, at the rate of $\theta=c / d$. Continuing with our numerical example, the new rate would be 5 percent on income of 200 and below. The old rate bands would be stacked on top of this new rate, i.e., 10 percent on income of 201 up to 1,200, and 20 percent on income above 1,200 . The new rate schedule would produce the following result.

\begin{tabular}{|c|c|c|}
\hline Income & $\begin{array}{c}\text { Marginal tax rate } \\
\text { (In percent) }\end{array}$ & $\begin{array}{c}\text { Tax liability with } \\
\text { tax credit } c=10\end{array}$ \\
\hline \multicolumn{3}{|c|}{} \\
\hline 200 & 5 & 0 \\
\hline 1,000 & 10 & 80 \\
\hline 10,000 & 20 & 1,860 \\
\hline
\end{tabular}

As is evident, the tax liabilities at various income levels match exactly those under the earlier two-rate schedule with a deduction of $200 .^{27}$ In this sense, there is a fundamental equivalence between a deduction and a tax credit. The insertion of the new rate band together with the tax credit essentially duplicates the effect of the deduction. ${ }^{28}$

It is worth noting that the above equivalence result is predicated on neither the number of rates in the original rate schedule nor the income of the taxpayer. This can be readily illustrated graphically in Figure 2, where $O A$ is the deduction and $A B C$ is the original tworate schedule. The elimination of the deduction shifts the rate schedule horizontally to the left until it emanates from the origin, as denoted by $O E F$. The introduction of a new first rate band at the rate $\theta=P A / O A$, in conjunction with stacking the original rate bands on top of it, results in the tax schedule $O P Q R$. Finally, a tax credit equal to $P A$ shifts $O P Q R$ vertically down so that the segment $P Q R$ coincides with the segment $A B C$ on the original tax schedule. Clearly, the number of rates in the original schedule or the income of the taxpayer is immaterial to this demonstration.

The equivalence result is illuminating, but its validity is limited to handling a single personal allowance. In reality, where multiple allowances and multiple rates are the norm, the choice between deductions and tax credits remains an important one. While there is no consensus in the literature on this issue, most would agree that the case for deduction is the strongest with

\footnotetext{
${ }^{27}$ Note that under the earlier tax schedule, a taxpayer with an income of 200 would incur no tax liability, due to the available deduction.

${ }^{28}$ This important insight is due to Sunley (1977). As noted earlier, a deduction of $d$ is equivalent to an initial zero-rate band of size $d$. However, this initial zero-rate band is, in turn, equivalent to an initial rate band at the rate $c / d$ combined with a non-refundable tax credit $c$.
} 
Figure 2. Equivalence Between a Deduction and a Tax Credit

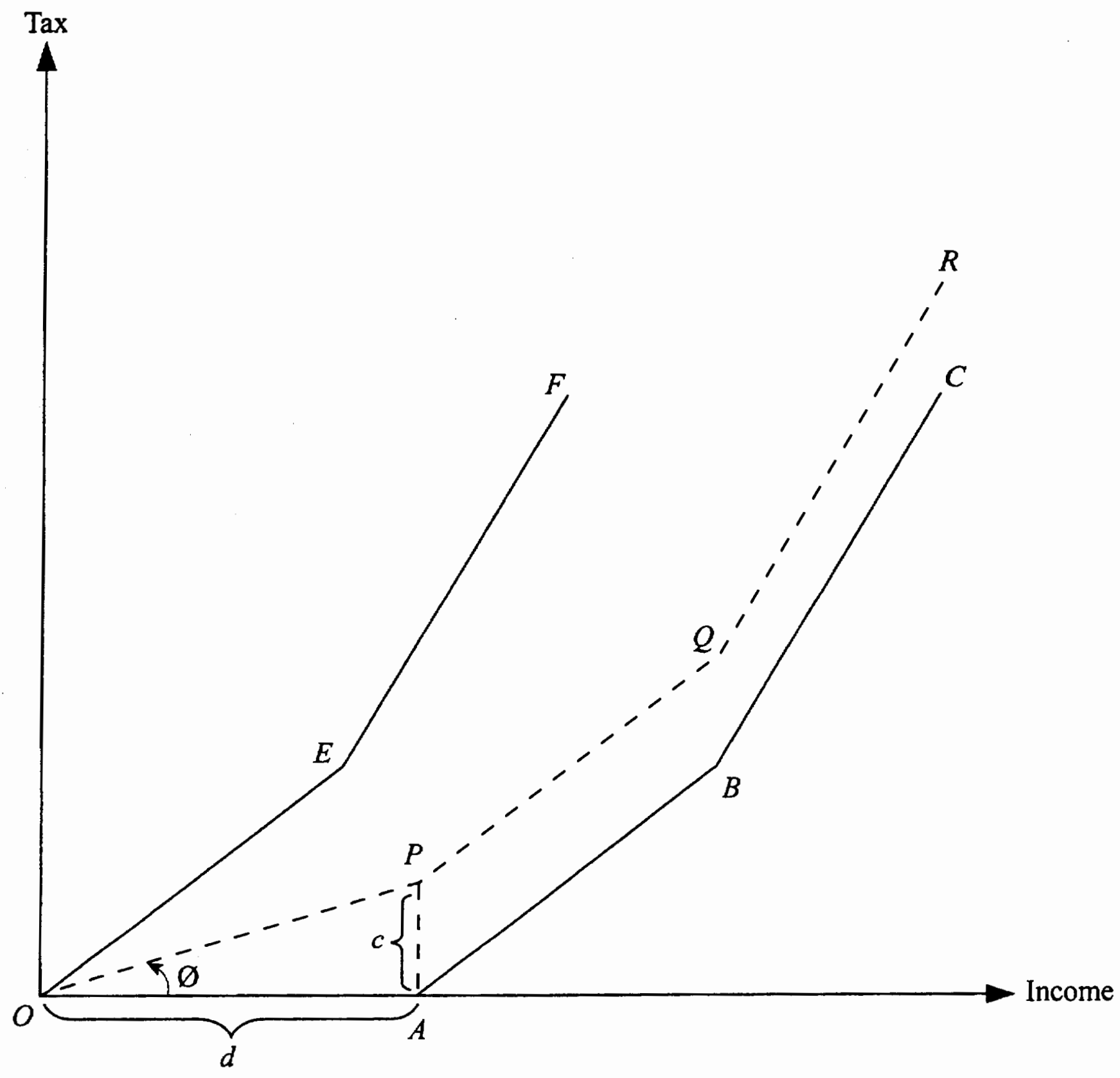


respect to the general (basic) allowance, while tax credits are more equitable when it comes to targeted allowances.

\section{Negative Income Tax}

If the subsistence justification for granting a general (basic) allowance noted earlier is accepted, then it would seem logical to argue that an individual whose pretax income is below some minimum level should obtain a subsidy from the income tax system (i.e., a negative income tax). Of course, direct welfare payments are an alternative means of delivering financial assistance to the poor, but such payments have long been criticized for their work-disincentive effects, as they are usually discontinued when recipients find work. Many economists have argued that the adverse incentive effects of direct welfare payments could be overcome if they are replaced by a negative income tax.

The simplest form of a negative income tax would be to let $t$ in equation (12) to go negative when $y<e$. In essence, the taxpayer is subject to the regular PIT (equaling $\tau \cdot y$ ) less a tax credit (equaling $\tau \cdot e$ ), with any excess tax credit refunded. Under such a scheme, $e$ should now be interpreted as the break-even level of income (i.e., no subsidy is paid when $y=e$ ) and $\tau \cdot e$ the guaranteed level of income (i.e., it is the subsidy amount when $y=0$ ). This scheme preserves work incentives because the post-tax income $(z)$ of an individual-inclusive of any subsidy_necessarily rises with pretax income, since

$z=y-t=(1-\tau) \cdot y+\tau \cdot e$

Hence, in theory, replacing direct welfare payments with a negative income tax should enhance the supply of labor. ${ }^{29}$ The downside of the negative income tax is that the nonpoor may well receive a significant share of its benefit (depending on the tax rate, the level of break-even income could be substantially higher than that of the guaranteed income ${ }^{30}$ ), thus imposing a large budgetary cost.

The PIT in the United States contains a limited negative income tax element known as the earned income tax credit, which operates by providing a refundable tax credit as a fixed percentage of earned income up to a given income threshold. ${ }^{31}$ It has grown over the years

\footnotetext{
${ }^{29}$ This outcome seems to have been borne out by several empirical studies on the labor-supply effects of the earned income tax credit (a limited version of the negative income tax) in the United States. See, for example, Scholz (1996) and Meyer and Rosenbaum (2001).

${ }^{30}$ For example, with a tax rate of 20 percent, a guaranteed income of 10,000 would correspond to a break-even income of 50,000 .

${ }^{31}$ The actual design of the earned income tax credit scheme is quite complicated. Among other things, the income threshold is dependent on the number of qualifying children, and the credit is phased out over a higher range of income to prevent the relatively well-off from benefiting from the scheme. Note that this phasing out of the credit has the effect of increasing the marginal tax rate of those with income in the phase-out range, which tends to reduce their labor supply. For a brief description of the history and design of the earned income tax credit, see United States (1995).
} 
into a very costly program. In FY 2001, it led to a reduction of about US \$4.2 billion in PIT revenue and incurred an outlay of about US \$25.8 billion in expenditure, for a total cost of about US $\$ 30$ billion ( 0.3 percent of GDP). ${ }^{32}$

\section{Treatment of Pension Schemes ${ }^{33}$}

Funds flowing through a pension scheme can be broken down typically into three stages: (1) the contributory stage, when funds enter the scheme as contributions from participants: (2) the investment stage, where contributions are invested in income-generating assets within the scheme; and (3) the payout stage, where pensions are withdrawn by retirees. Tax issues can arise, therefore, at each of these stages. Specifically, whether (1) contributions are deductible under the PIT; (2) investment income within the pension scheme is taxable; and (3) pensions are taxed under the PIT.

To see the tax implications of the interactions among the stages, consider the simple example of an individual making a contribution $p$ to the pension scheme at the beginning of a year and withdraws his pension at the end of the year in the amount of his initial contribution plus whatever returns (say, at the pretax rate $r$ ) it has earned within the scheme. All transaction costs are assumed to be nil for simplicity. Suppose the individual faces a PIT rate of $\tau_{1}$ at the time of his contribution. If the contribution is tax deductible, it would yield a tax saving of $\tau_{1} \cdot p$, thus reducing the cost of the contribution to $\left(1-\tau_{1}\right) \cdot p$. Should the returns earned within the scheme be taxable (say, at the rate $\tau_{2}$ ), then the pension payout would be $\left[1+r \cdot\left(1-\tau_{2}\right)\right] \cdot p$. Finally, the pension itself could be subject to the PIT (say, at the rate $\tau_{3}$ ) at the time of the payout, in which case the individual's after-tax pension would be $\left[1+r \cdot\left(1-\tau_{2}\right)\right] \cdot\left(1-\tau_{3}\right) \cdot p$. The rate of return $(\rho)$ to the individual from participating in the pension scheme is, therefore, the ratio of his after-tax pension to the cost of contribution minus one, or

$\rho=\left[1+r \cdot\left(1-\tau_{2}\right)\right] \cdot\left(1-\tau_{3}\right) /\left(1-\tau_{1}\right)-1$.

Several important implications can be drawn from equation (18). First, if $\tau_{3}=\tau_{1}$ (i.e., pension is taxed at the same rate as the relief given to the contribution), then $\rho=r \cdot\left(1-\tau_{2}\right)$, so that only the tax rate on the return earned within the pension scheme matters. The benefit of the deductibility of the contribution is offset completely in this case by taxing the pension at the same rate. Second, if, in addition to $\tau_{3}=\tau_{1}, \tau_{2}=0$ (i.e., the returns earned within the pension scheme is tax exempt), then $\rho=r$, so that the net effect is that savings channeled through the pension scheme escapes taxation altogether. Hence, participation in the scheme would confer substantial tax benefit if the returns from regular savings (i.e., outside the scheme) are subject to tax (as is usual under a typical PIT).

\footnotetext{
32 There is now a large literature on the economic effects of the earned income tax credit scheme in the United States. For a succinct analysis, see Browning (1995).

${ }^{33}$ The discussion in this section is drawn from King (2004).
} 
Finally, if $\tau_{2}=\tau_{3}=0$ (i.e., returns earned within the pension scheme as well as pension payout are tax exempt), then $\rho=(1+r) /\left(1-\tau_{1}\right)-1>r$. In other words, the tax treatment of the pension scheme in this case actually results in an effective subsidy to savings channeled through the scheme.

The decision on how pension schemes should be treated under the PIT should be based on a clearly articulated public policy objective regarding savings, as well as on a well thoughtthrough role for tax policy to play to achieve that objective, after taking due consideration of all the associated costs and benefits. A tax policy that favors one saving vehicle, such as pension schemes, over others (such as life insurance) need to be carefully justified, especially if the policy involves not only a reduction in taxation, but actually granting a subsidy. If pension schemes are tax-favored, penalties would need to be imposed on early withdrawals.

The PIT treatment of pension schemes in most OECD countries follow broadly the model of setting $\tau_{3}=\tau_{1}$ and $\tau_{2}=0$ (although limitations are typically imposed on the extent to which contributions are deductible). As noted earlier, this model results in exempting savings channeled through pension schemes from tax. ${ }^{34}$ To the extent that such savings constitute a major share of total savings, this treatment effectively transforms, to a significant degree, the PIT into a consumption-based tax (see further discussion in Section VI below).

\section{E. Treatment of Capital Income}

Arguments for and against aggregating capital income with labor income for PIT purposes have already been reviewed earlier in Section II. Here, the focus is on some structural aspects of the tax treatment of the three main forms of capital income (interest, dividends, and capital gains), assuming the policy decision has been made to subject them to tax on either a schedular or aggregative basis.

\section{Interest}

There are three main issues of conceptual interest when it comes to the PIT treatment of interest: (1) neutrality in taxing interest income from different financial instruments; (2) accrual basis for taxation; and (3) the deductibility of interest expenses.

\section{Neutrality in taxing interest income}

The first and foremost issue in taxing interest income is whether all interest should be treated alike, or some forms of interest be given preferential tax treatment to promote targeted financial instruments. The most common example of a tax-preferred financial instrument are tax-exempt government bonds, which can be found in many countries, both developed and

\footnotetext{
${ }^{34}$ It is interesting to note that the United States utilizes two versions of this model in its PIT treatment of individual retirement accounts (IRAs): $\tau_{3}=\tau_{1}=$ applicable marginal tax rate on personal income (regular IRAs) and $\tau_{3}=\tau_{1}=0$ ("Roth" IRAs).
} 
developing. The question that naturally arises is whether such a practice is effective in achieving its stated purpose.

Consider first the case of a closed economy. If capital markets are perfect, arbitrage by savers should equalize the after-tax rates of return across different financial instruments (of the same risk class). Hence, if $r_{t}$ is the pretax interest on taxable government bonds, $r_{e}$ the interest on tax-exempt government bonds, and $\tau$ the applicable PIT rate, then the following condition would hold:

$r_{t} \cdot(1-\tau)=r_{e}$,

which implies that the pretax interest on taxable bonds would exceed the interest on taxexempt bonds by exactly the tax differential, rendering both types of bonds equally attractive to savers as well as equally costly to the government budget in net terms (gross interest cost less any tax collected on the interest). It would thus seem that the objective of issuing taxexempt government bonds (or granting tax preferences to targeted financial instruments) would be thwarted by arbitrage.

The above conclusion would need to be qualified, of course, if capital markets are imperfect because of impediments to the free flow of funds across different financial instruments, since in this case equation (19) would no longer hold. It would also need to be qualified if savers face different marginal tax rates, as would be the case if the PIT has a multi-rate schedule: the $\tau$ in equation (19) would then represent the rate of a marginal saver who is just indifferent between the two types of bonds after arbitrage has brought about adjustments to $r_{t}$ and $r_{e}$ to satisfy equation (19). Savers whose marginal tax rates are higher than $\tau$ would clearly prefer to hold tax-exempt bonds, and their gains from doing so would be at the expense of the budget. Hence, tax-preferred financial instruments tend to benefit primarily the relatively well-off, which may be an unintended distributive consequence.

In an open economy, the economic consequences of nonneutral tax treatments of different financial instruments will hinge on the tax rules adopted at home and by other countries as regards cross-border income flows. If all countries have residence-based tax systems, a saver's after-tax returns would be solely determined by the tax rate in his home country. Thus, foreign savers would have no interest in a country's tax-exempt government bonds as long as $r_{t}>r_{e}$. In contrast, under a regime of source-based tax systems, after-tax returns are determined by the tax rate in the saver's host country. In this latter case, foreign and domestic savers are on level grounds and the earlier discussion relating to the closed economy will again apply. ${ }^{35}$ While in practice the international tax rules are characterized by a hybrid regime of residence- and source-based systems - thus rendering it difficult to arrive at a neat description of the outcome, it remains the fact that most developed and capital-exporting

\footnotetext{
${ }^{35}$ Of course, foreign savers may well face a different tax rate (typically the withholding tax rate on interest) in the host country from that (typically the regular PIT rate) applicable to domestic savers. However, this situation is no different from one in which domestic savers themselves are subject to different PIT rates.
} 
countries tax interest income on a residence basis. Hence, on the whole, the case for the nonneutral tax treatment of different financial instruments is fairly weak. ${ }^{36}$

\section{Accrual basis for taxation}

Interest income is usually taxed on an accrual basis in developed countries. Measuring accrued interest from certain debt instruments is not always straightforward, however, since such interest could be capitalized in their prices. Typical examples would be debt instruments with a maturity date longer than a year acquired at a discount (i.e., the acquisition price being below the redemption value), either as original issues or in the secondary markets. The discount represents interest spread over the life of the debt and should be properly brought to tax as such as it accrues. Failure to do so could result in a substantial delay in tax payments.

Two alternative methods of computing accrued interest from discount debt instruments are commonly used by countries for tax purposes: the pro-rata method and the constant-yield method (or some variation of either method). The former method prorates the total discount of an instrument as taxable interest in accordance with its holding period as a fraction of its life determined by the dates of acquisition and maturity. The later method first computes the constant average compound interest rate as implied by the discount and then calculates the taxable interest over the holding period accordingly. Since the pro-rata method ignores compounding, it overstates (understates) the true interest income in early (later) years of the holding period, and could thus invite abuse. ${ }^{37}$

\section{Deductibility of interest expenses}

The treatment of interest expenses incurred in association with the production of business income taxable under the PIT (such as that derived by the self-employed) should ideally conform with the treatment of such expenses under the CIT; a less favorable treatment could provide an incentive for entrepreneurs to incorporate themselves solely for tax reasons.

In most developed countries, some types of nonbusiness-related interest expenses are often also deductible under the PIT, the prime example of which being mortgage interest, especially connected with the principal residence (though the allowed deduction is usually subject to limitations). The promotion of home ownership seems more a matter of social rather than economic objective, but the use of tax policy to achieve it inevitably entails a budgetary cost (in addition to other distortive effects) that could well be significant. ${ }^{38}$

\footnotetext{
${ }^{36}$ See Norregaard (1997) for an extended discussion of the various issues related to the tax treatment of government bond interest.

${ }^{37}$ For example, when interest expenses are deductible (see below), a taxpayer could borrow from tax-exempt entities by issuing discounted debt, thus benefiting from the overstated interest payments under the pro-rata method.

${ }^{38}$ In the United States, for example, the mortgage interest deduction reduced the PIT revenue by about US $\$ 63$ billion (0.6 percent of GDP) in FY 2001.
} 
Another important deduction concerns interest incurred to undertake passive (i.e., nonbusiness) investments. While some countries permit it, this deduction clearly allows the taxpayer to shift a part of the risks associated with such investments to the government up front, which seems ill-advised as a matter of policy.

\section{Dividends}

Since most dividends are presumably paid out of corporate profits that were already subject to the CIT, the central issue is one of double taxation if they are to be taxed again under the PIT. A tax system that provides no relief for this double taxation is known as a classical system. Relief, should it be deemed desirable, could, however, be given at either the corporate or the shareholder level. From the perspective of the PIT, it is of course relief at the shareholder level that is of interest and, consequently, the focus of the following discussion. ${ }^{39}$

There are two main categories of double-taxation relief for dividends at the shareholder level: (1) imputation; and (2) reduced taxation.

\section{Imputation}

An imputation system first imputes the CIT paid by a corporation on its distributed profits to its shareholders, and then grants a full credit for the said CIT against their PIT on such profits. If $q$ represents the dividends paid out of taxed profits of a corporation, the PIT on the shareholder (assuming he also has nondividend income $y$ ) under an imputation system would be computed as follows:

$t=\tau \cdot[y+q /(1-\delta)]-q \cdot \delta /(1-\delta)=\tau \cdot y+q \cdot(\tau-\delta) /(1-\delta)$,

where, as before, $\tau$ is the applicable PIT rate, $\delta$ is the CIT rate, and $t$ is the total PIT liability. Hence, the shareholder effectively pays PIT on the dividends grossed up by the underlying CIT (represented by the term $q /(1-\delta)$ ) and obtains a credit for the CIT so paid (represented by the term $q \cdot \delta /(1-\delta))$. The overall result is that distributed corporate profits are taxed at the PIT rather than the CIT rate. As such, the imputation system not only eliminates the double taxation of dividends, it also consolidates dividends with other income of the shareholder for PIT purposes, and is thus fully compatible with the global income approach to taxation. For this reason, the CIT and the PIT are said to be integrated under the imputation system. ${ }^{40}$ Almost without exception, imputed credits are not available to non-resident shareholders.

\footnotetext{
${ }^{39}$ Relief at the corporate level could take one of two main forms: (1) a split-rate system, whereby distributed profits of a corporation are subject to a lower CIT rate than its retained earnings; and (2) a dividend deduction system, whereby distributed profits, like interest, are treated as a deductible expense under the CIT (but are subsequently taxed under the PIT).

40 Technically, the imputation system integrates the CIT with the PIT at the shareholder level, while the dividend deduction system integrates the two at the corporate level.
} 
Since the shareholder is granted a credit that equals the full imputed CIT, but taxed only at the applicable PIT rate on the imputed credit, care must be taken to ensure that only dividends for which the underlying CIT has actually been paid at the corporate level qualify for the imputation at the time imputed credits are granted. Otherwise, excess relief to the shareholder would result. To this end, the usual practice in countries operating an imputation system is to require corporations to establish a so-called "franking" account to keep track of all declarations of dividends. The machinations of the franking account vary in complexity across countries, but the underlying principle is straightforward and can be easily described: a credit entry to the account arises whenever a CIT payment is made, while a debit entry arises whenever dividends are declared - the debited amount being the imputed CIT, i.e., $q \cdot \delta /(1-\delta)$. At the end of the tax year, a debit balance in the account would result in a franking charge to the corporation to bring the account to zero, while a credit balance would be carried forward for franking future dividends. In this way, dividends received by shareholders are always franked and, therefore, eligible for receiving imputed credits.

\section{Reduced taxation}

Other methods of eliminating or at least reducing the degree of double taxation of dividends at the shareholder level are available and could be used if taxing personal income on a global basis is not a policy objective. Some notable examples in this regard are (1) exempting dividends from the PIT in whole or in part; (2) applying a lower PIT rate on dividends than that on ordinary income; and (3) granting a tax credit on account of the dividends received (but the credit so granted is not necessarily equal or even tied to the underlying CIT paid). Tax systems using these methods are sometimes referred to as modified classical systems. ${ }^{41}$

\section{Discussion $^{42}$}

There are arguments both for and against integrating CIT with PIT through imputation. Proponents of integration note that: (1) corporations are not taxable entities independent of shareholders; (2) nonintegration raises the cost of corporate capital and discourages investment; and, most importantly, (3) nonintegration violates neutrality with respect to the tax treatments of investment between corporate and noncorporate sectors; debt and equity financing; dividends and retained earnings; and different forms of capital income. ${ }^{43}$

Critics of integration, however, point out that: (1) corporations, as legal persons, are separate entities from shareholders; (2) the effects of double taxation of dividends are fully capitalized in share prices, thus integration will have no impact on the cost of corporate capital and investment, but will simply confer a windfall gain to existing shareholders and necessitate alternative - possibly more distortive and administratively costly - taxes to compensate for

\footnotetext{
${ }^{41}$ For an exhaustive treatment of different approaches to double taxation relief for dividends, see Harris (1996).

42 This section draws from Zee (2002).

${ }^{43}$ For elaboration of these points, see United States (1992).
} 
the associated revenue loss; ${ }^{44}$ (3) the incidence of the CIT is progressive-it falls primarily on shareholders who are usually better off than others; and (4) integration through imputation discriminates against foreign shareholders, since they do not receive the imputed credits.

On balance, there is broad consensus among economists on the undesirability of the double taxation of dividends, but much less agreement on the preferred method to alleviate it. Thus, most developed countries (including the United States following the passage of new tax legislation in 2003) grant double taxation relief at least to some extent, with imputation being the most common method of providing such relief. However, concerns about discrimination against foreign investors (among other things) have prompted some countries, e.g., Germany and the United Kingdom, to replace their imputation with modified classical systems recently. ${ }^{45}$ Moving away from the imputation system is de facto a move away from the global income and towards the schedular approach to taxation.

\section{Capital gains}

In principle, there is little justification for treating capital gains differently from other forms of capital income in a tax system. In practice, taxing capital gains raises a number of issues that are not present - or at least not present as prominently - in taxing, for example, interest and dividends. ${ }^{46}$ First, capital gains, especially gains derived from some forms of innovative financial instruments (i.e., derivatives), can be difficult to identify and measure correctly. Second, capital gains from most assets are administratively costly to tax (in terms of both compliance and enforcement) on an accrual basis. ${ }^{47}$ For this reason, such gains, if taxable, are almost without exception taxed upon realization, which can distort a taxpayer's decision on the timing of realizing the gains (or losses) for tax reasons alone. ${ }^{48}$ Finally, withholding taxes (see below), commonly applied to interest and dividends to reduce evasion, are administratively infeasible to apply to capital gains on a broad scale (and in fact no country applies it as such). ${ }^{49}$

\footnotetext{
${ }^{44}$ See Sørensen (1995) for a detailed discussion on this point.

${ }^{45}$ Issues related to the tax treatment of foreign-source dividends received by domestic residents are discussed below in connection with foreign tax credits.

${ }^{46}$ Throughout the discussion, the focus is on capital gains received by individuals as investment income. Capital gains received by those in the course of their business operations (e.g., dealers of financial and nonfinancial assets) are business income and should be taxed as such.

${ }^{47}$ Exceptions would be assets that are widely traded in the market on a continuous basis (e.g., futures contracts), so that changes to their values can be easily ascertained by marking them to market at regular intervals.

${ }^{48}$ Theoretically, the timing distortions (postponement of gains - commonly referred to as the "lock-in" effector acceleration of losses) of capital gains taxation can be overcome by retrospective taxation. This is, however, very much an unproven approach in practice (Italy is the only country that had once adopted a version of a retrospective tax). For further discussions of retrospective taxation and the relevant literature, see Zee (2004b).

${ }^{49}$ China subjects capital gains from bonds to a withholding tax (collected by brokers).
} 
Two further important issues relating to the PIT treatment of capital gains need to be addressed - both arise as a result of such gains being taxed on a realization basis. The first is whether long-term gains (gains from assets held for typically more than a year) should be preferentially treated relative to short-term gains. Many countries do so, for the fairly compelling reason that a significant fraction of long-term gains could in fact represent only the effects of inflation rather than real economic gains.

The second issue has to do with the deductibility of capital losses, as well as whether such losses realized in a given tax year could be carried forward into subsequent years to offset future income. Because the timing of the recognition of capital losses for tax purposes, like gains, are at the discretion of the taxpayer, tax rules are needed for the treatment of such losses to prevent abuse. Country practices vary, but generally capital losses would be deductible if capital gains are taxable, although the recognition of any capital loss is often subject to a so-called "wash rule" that specifies the minimum period of time that must elapse before the same asset (e.g., a stock) that was initially sold to generate the loss could be rebought. It is also common to limit the number of years capital losses could be carried forward, and in some countries such losses are only permitted to offset capital gains. The ultimate objective of all such rules is, of course, to safeguard revenue by limiting tax abuse.

\section{Withholding taxes}

A noted earlier, withholding taxes on interest and dividends (but not on capital gains) are common in almost all countries. An issue that needs to be addressed in imposing such taxes is whether they should be considered final, or simply advance payments that are fully creditable in computing the ultimate tax liability of a taxpayer.

For domestic recipients of interest and dividends, final withholding taxes on such income could be an extremely useful device to simplify tax administration, in that - in conjunction with the almost universal pay-as-you-earn system of withholding on wage income ${ }^{50}$ - they would obviate the requirement for taxpayers to file year-end tax returns, except for those who have business income (or other types of taxable income not subject to final withholding). In fact, it can be expected that a system of final withholding taxes on interest and dividends would reduce the number of taxpayers with filing obligations to only a small fraction of the total PIT-paying population, thus substantially easing the administrative burden of the tax. However, final withholding taxes are fundamentally incompatible with a PIT that is based on the global income approach, unless the PIT has only a single rate that is equal to the uniform final withholding rate on both interest and dividends. It is also important to ensure that, when this latter condition does not hold, withholding on interest received by taxpayers with business income should not be final (regardless of how the withholding is applied elsewhere). For these taxpayers, where interest payments are presumably a deductible expense, a final

\footnotetext{
${ }^{50}$ For a detailed discussion of the pay-as-you-earn system, see van der Heeden (1998).
} 
withholding tax on interest income that is below their applicable marginal PIT tax rates could provide them with a strong incentive to engage in tax-avoiding arbitrage transactions. ${ }^{51}$

Withholding taxes on interest and dividends paid to nonresidents are necessarily final from the perspective of the source country. The rate of such taxes are typically governed by relevant bilateral tax treaties. It is useful to note that the OECD model tax convention limits the withholding rate on interest to 10 percent and dividends to 15 percent ( 5 percent if the recipient is a company owning at least 25 percent of the dividend-paying company). ${ }^{52}$

\section{F. Treatment of Perquisites}

In principle, there is no basis for treating perquisites (fringe benefits), in cash or in kind, received by employees differently from their wage income under the PIT. Indeed, any differential tax treatment between the two could lead to serious abuse, as has been borne out the experiences of several countries that had at one time or another exempted certain perquisites from tax. ${ }^{53}$ In practice, not all perquisites - especially those paid in kind - can always be adequately brought to tax even if the tax legislation explicitly provides for their taxation. The best one can hope for would be to ensure that the more common and significant ones (e.g., employer-provided accommodations; employer-provided vehicles and other transportation allowances; food discounts; employer contributions to medical insurance; education assistance; and subsidized loans) do not escape the tax net.

Perquisites can be taxed in essentially three different ways: (1) in the hands of the employee - this approach requires the proper valuation (when paid in kind) and declaration of perquisites received, and is thus administratively the most difficult approach to enforce (although it is ironically the most widely-used); (2) in the hands of the employer by denying the tax deductibility of perquisites paid - this approach effectively taxes the perquisites at the CIT rate and is easier to enforce than the first approach (since the cost of perquisites to the employer is more readily ascertainable); and (3) through the adoption of a separate fringe benefits tax to be paid by the employer - this approach is capable of overcoming the limitation of the second approach when the perquisite-paying employer is CIT-exempt, and

\footnotetext{
${ }^{51}$ Consider two individuals, $X$ and $Y$, each with taxable business income of 100 and face the same common applicable marginal PIT rate of 30 percent. Under normal circumstances, each would be liable for a PIT of 30 on this income. This tax can be avoided, however, if $X$ were to lend $Y$, say, an amount of 10,000 at an interest rate of 10 percent, and $Y$ were to lend the same amount back to $X$ at the same rate. With this arrangement, the two individuals would simultaneously receive 100 in interest income from, and pay 100 in interest expense to, each other, with no net cash flows need to occur between them-but the taxable business income of each would now be reduced to nil. Thus, if the final withholding tax on interest is, say, 20 percent, each individual would be liable to only 20 in PIT, resulting in a tax saving of 10. Tax arbitrage of this sort is extremely difficult to detect, especially if the back-to-back loan is arranged through an unrelated third party (typically for a nominal fee).

${ }^{52}$ See OECD (2000). See also Zee (1998) for a general discussion of the economic effects of withholding taxes on cross-border flows of capital income.

${ }^{53}$ For example, the exemption of housing allowances provided by employers to employees in a certain country resulted in the payment of most wages in that country in the form of such allowances.
} 
has the added flexibility of taxing the perquisites at a rate different from the CIT rate. The third approach has been adopted by Australia and New Zealand (in both countries, the fringe benefits tax rate is higher than the CIT rate). ${ }^{54}$

\section{G. Treatment of the Self-Employed}

In most developed countries, business income of the self-employed is determined according to the same rules that are used to determine corporate profits, although in a number of countries the accounts of the self-employed are allowed to be kept on a simplified basis. Personal allowances and other deductions available under the PIT are then applied to the business income so determined to arrive at the taxable income - and taxed in accordance with the PIT rate schedule. In some countries, special tax arrangements (e.g., flat-rate schemes) are available for the self-employed meeting certain qualifying conditions. ${ }^{55}$

An important issue related to taxing the self-employed is that the income of this class of taxpayers is really an amalgamation of wages and profits. This would present no problem to a PIT that makes no attempt to separate the two. Some PITs do, however, as in dual income tax systems (Chapter VI). The associated complications are discussed there in that context.

\section{H. Residence Rules and Foreign Tax Credits}

Residence rules are necessary in any tax system. For the PIT, they determine how an individual is treated for tax purposes regardless of his nationality or citizenship. Residence rules may also help determine the source of an income (e.g., it may be sourced in a country if it is paid by a resident of that country). While rules vary in detail, most countries employ a domicile test in conjunction with a physical presence test: an individual is considered a resident in a given tax year if he has a domicile in the country or is physically present in the country for more than a given number of days (typically 183 days) over a given period of time (typically the current tax year). ${ }^{56}$ In a residence-based tax system, as a rule residents are taxed on their worldwide income, with credits given for foreign taxes paid (further discussed below), while nonresidents are taxed only on their domestically sourced income. In a sourcebased tax system, it is, of course, only the source taxes matter. However, as noted earlier, the tax systems of most countries are hybrids, and may treat different types of income differently. For example, employment income may be accorded a different tax treatment from capital income, and, within capital income, a distinction may be drawn between interest and dividends.

\footnotetext{
${ }^{54}$ Burns and Krever (1998) reports that a separate fringe benefits tax has also been adopted in some transition and developing countries.

${ }^{55}$ For a survey of practices in OECD countries, see OECD (1994).

${ }^{56}$ It is interesting to note that the United States would regard an individual resident for tax purposes if he either is a U.S. citizen or holds an alien registration ("green") card, even if he is neither domiciled nor physically present in the country. The green card test is unique.
} 
For income received by a resident derived from employment in a foreign country, the OECD model tax convention awards the rights to tax that income to the resident's home country if the resident's presence in the foreign country does not exceed an aggregate of 183 days. Such a rule is broadly followed by most countries. Any foreign taxes paid on employment income are almost without exception creditable against any domestic taxes on such income. In contrast, the tax rights to interest and dividends under the convention are shared between the host (where the income is paid) and the home (where it is received) countries, albeit with limitations on the rights assigned to the former (in the form of withholding ceilings, as noted earlier). The home countries face no such restrictions under the convention, and in practice typically elect to treat foreign-source interest differently from foreign-source dividends.

While foreign-source interest is typically taxed on a residence basis in most countries (as noted earlier) - with credits granted for foreign withholding taxes, the treatment of foreignsource dividends could vary depending on a number of considerations, e.g., the ownership share of the resident in the foreign corporation paying the dividends. For example, if this share exceeds a certain threshold, a country could elect to tax the dividends on either the source basis (no further domestic taxes are imposed) or the residence basis (credits against the domestic taxes are given for both the underlying foreign CIT and the foreign withholding tax). However, if the ownership share falls below the specified threshold, tax credits for foreign-source dividends could be limited to foreign withholding taxes only.

As a rule, the maximum foreign tax credits available are limited to the domestic tax liability on foreign-source income, i.e., foreign taxes paid in excess of this amount are not refundable (for otherwise domestic tax collections would be dependent on the tax policies in foreign countries). This raises two further issues: (1) whether foreign tax credits should be segregated on a country-by-country and/or income-by income basis (i.e., no cross-crediting is allowed); and (2) whether excess foreign taxes in one period can be carried forward to subsequent periods (and for how long). How a country decides on these issues is largely a matter of balancing the objective of minimizing the double tax burden with that of safeguarding revenue.

\section{Design OF THE PIT: InTERgovernMental Dimension}

The inter-governmental dimension of the PIT is one aspect of a broader issue regarding the assignment of taxes and sharing of revenue between the central and subcentral governments, which, in turn, is itself a component of a still broader set of issues that frame the overall fiscal relationship among the different levels of government in a country. Considerations of these broader issues - which are undoubtedly underpinned as much by the country's history, culture, and institutions as by its economic system - are, however, beyond the scope of the present paper. ${ }^{57}$ Here, the discussion will be narrowly focused on the PIT alone. In this

\footnotetext{
${ }^{57}$ The literature on inter-governmental fiscal relations is voluminous. For a concise overview of issues, see Tanzi (1995). For a review of country practices, see Ter-Minassian (1997). The use of the term "fiscal federalism" is eschewed in this paper because relevance of the issues being discussed is not limited to countries that are federations.
} 
context, the main questions are whether the PIT should be assigned to the central or subcentral government, or whether it should be a shared tax. If the latter, whether the sharing should be in terms of revenue or taxing power as regards its base and rate schedule.

Conventional economic reasoning suggests that taxes that should be assigned to subcentral governments are those that have relatively immobile bases (to minimize tax competition), whose bases are relatively evenly distributed nationally (to avoid inequitable distribution of taxing capacity), and whose economic consequences are largely confined to the jurisdictions that impose them (to better align instruments with objectives). According to these criteria, the PIT does not emerge as a strong candidate for either a central or a subcentral tax: while its base (primarily labor income) is not exactly immobile, it is far less mobile than capital income or even consumption; its base is also no more unevenly distributed nationally than other broad-based taxes; and, finally, though its redistributive effects are normally more of a national rather than local concern, it is generally a relatively elastic tax that could serve the revenue objective of all levels of government well. These attributes of the PIT are highly suggestive of its suitability as a shared tax - a conclusion that is in fact strongly supported by country practices. In most developed countries, the PIT is indeed a shared tax, although the manner and degree of sharing could vary greatly from country to country. ${ }^{58}$

The spectrum of the PIT sharing arrangements is quite broad. At one end, only the central government imposes the PIT, but some fraction of the revenue so raised is transferred to subcentral governments. At the other end, the two levels of government impose independent PITs that differ in both the base and rate schedule. Nevertheless, a greater proportion of total PIT revenue accrues to the central government in a majority of OECD countries regardless of the sharing arrangement used.

The relative merits of different sharing arrangements are difficult to evaluate separately from the design and objectives of the overall system of inter-governmental fiscal relations. There is, however, one tradeoff inherent in the sharing of the PIT that is noteworthy in and of itself: that between policy discretion and administrative costs. For example, if the sharing involves only revenue - with the tax being imposed by the central government alone, then subcentral governments effectively have given up policy discretion as the price for incurring no administrative costs. In contrast, while a high degree of policy discretion could be enjoyed by both levels of government if they impose completely independent PITs, this benefit may well entail too high an administrative burden on many subcentral governments (since by definition they cannot exploit the economy of administrative scale to the same degree as the central government). Hence, the case is quite compelling for the base of the PITs at the subcentral government level (if imposed at all) to share some commonality with the central government's PIT base. An extreme form of base harmonization would be for subcentral governments to impose PITs with rates that merely "piggy-back," or act as surcharges, on the

\footnotetext{
${ }^{58}$ For a survey of practices in OECD countries, see OECD (1999).
} 
PIT rates of the central government. In this way, some degree of policy discretion-in setting rates - is preserved at minimal administrative costs to subcentral governments. ${ }^{59}$

\section{Alternative Designs of the PIT}

Concerns about the disincentive effects on savings of taxing capital income, coupled with the increasing global mobility of capital, have prompted a serious reexamination by economists and policymakers alike on the advisability of designing the PIT in accordance with the global income approach. Two alternative designs of the PIT have received a great deal of attention in recent years. The first — and the more radical — attempts to remove the tax burden on capital income completely, thus resulting in a PIT that effectively targets consumption as its tax base, while the second - which has already been implemented in a few Nordic countries - explicitly taxes capital income at a lower rate than labor income, thus effectively implements the PIT on a schedular basis. ${ }^{60}$

\section{A. Targeting Consumption}

By definition, the tax object of an income tax is income. In what sense, then, can a tax on personal income be regarded as a tax on consumption? It is in the sense that taxing labor income is equivalent to taxing consumption over the life cycle of a taxpayer. This outcome can be achieved through two alternative, but equivalent, reforms to a conventional PIT: (1) shifting the base of the PIT to wages only (the wage tax); and (2) allowing a deduction for savings (the expenditure tax). The well-known "flat tax" and "USA tax" proposals correspond to the wage tax and expenditure tax ideas, respectively, although each also includes a proposal to convert the conventional CIT into a consumption-based tax as well.

\section{Wage tax}

Consider the simple case of an individual who lives for two periods: works in the first and retires in the second. In the first period, he receives $y$ in pretax wages, spends $x_{1}$ on consumption, and saves $v$ for his retirement. Let $\tau$ be the PIT rate as before. Then his firstperiod budget constraint is simply

$(1-\tau) \cdot y=x_{1}+v$

In the second period, the individual, being retired, lives on his savings for which he has earned a return at the rate $r$. If the PIT does not tax this return, his second-period budget constraint would be

$(1+r) \cdot v=x_{2}$,

\footnotetext{
${ }^{59}$ While a piggy-back rate is necessarily flat, it clearly does not have to be uniform across the entire rate schedule of the host tax.

${ }^{60}$ The rest of this chapter draws in part from Zee (2002).
} 
where $x_{2}$ is his second-period consumption. Combining equations (21) and (22) yields the individual's life-time budget constraint as

$(1-\tau) \cdot y=x_{1}+x_{2} /(1+r)$,

which says nothing more than the fact that the present value of life-time consumption must be equal to life-time after-tax income. ${ }^{61}$ However, equation (23) also makes it clear that taxing wages at the rate $\tau$ is equivalent to taxing consumption in both periods at a rate equal to $\tau /(1-\tau) .{ }^{62}$ Hence, a 10 percent tax on wages is roughly equivalent to a 11.1 percent tax on consumption. Of course, the two forms of taxation entail different time profiles of tax payments: the entire tax is paid in the first period in the case of the wage tax, while a part of the tax is delayed until the second period in the case of the consumption tax. The cost (benefit) of this delay in present-value terms to the government (individual) is precisely offset, however, by the latter tax's larger total nominal tax payment over the two periods. ${ }^{63}$

The upshot of the above analysis is that, once one adopts a life-cycle perspective, income and consumption are far less clear-cut than usually thought, because income in one period, even if saved, would have to be consumed in some future periods. Hence, the difference between a wage tax and a consumption tax merely amounts to one of timing in tax collections rather than economic substance. In contrast, a conventional PIT that taxes the return to savings does entail a substantive economic consequence - the distortion to savings behavior - not shared by the wage tax. A PIT that taxes wage income only is thus effectively a consumption tax.

\section{Flat tax ${ }^{64}$}

From the sole perspective of a tax on personal income, the flat tax is conceptually equivalent to a wage tax, except that its rate schedule is specifically stipulated to contain a single rate. ${ }^{65}$ But, as noted earlier, the objective of the flat tax is much broader than simply to reform the PIT; it aims to convert both the PIT and the CIT into consumption taxes with a single common rate. While reform of the CIT is beyond the scope of this paper, it is nevertheless instructive to describe, even if briefly, the full mechanics of the flat tax in this regard.

\footnotetext{
${ }^{61}$ This observation, suitably modified, remains valid in the presence of inheritance and bequests.

62 This equivalence result would hold even if the individual's labor supply is variable and affected by taxes - the consequent tax impact on labor supply would have been the same regardless of which tax is imposed.

${ }^{63}$ This is so because the consumption tax has a larger nominal tax base than the wage tax, as the former includes the return earned on savings that is used for consumption in the second period.

${ }^{64}$ First proposed by Hall and Rabushka (1995).

65 Technically, the flat tax is not entirely flat. To increase its political acceptability, the proponents of the flat tax allow an exemption threshold for wage income. This has the effect, as explained earlier, of imparting an average progressivity to the tax.
} 
From national income accounts, gross national income $(Y)$ can be expressed in two different ways. On the expenditure side, it is equal to the sum of consumption $(C)$ and investment $(I):^{66}$

$Y=C+I$,

while on the income side, it is equal to the sum of wages $(W)$, interest $(R)$, profits $(P)$, and depreciation $(D)$ :

$Y=W+R+P+D$

Furthermore, investment must be equal to savings $(S)$ by way of an accounting identity:

$I=S$

From equations (24)-(26), it is obvious that consumption can also be expressed in two different ways:

$C=Y-S=W+R+P+D-I$.

The base of a conventional PIT is $W+R$ (as well as $P$ if distributed and subject to the PIT in the hands of the shareholder), while that of a conventional CIT is $P$. In calculating $P$, conventional accounting rules treat $W, R$, and $D$ as deductible expenses, but do not allow $I$, or expenditure on capital equipment, to be deducted at the time it is incurred.

Under the flat-tax proposal, the base of the CIT would be shifted from $P$ to $F$, where

$F=P+R+D-I$

In other words, in calculating the taxable profits of a corporation under the flat tax, interest and depreciation are no longer considered to be deducted expenses, but a deduction for capital expenditure is now allowed. The simultaneous removal of depreciation and incorporation of a full deduction for capital expenditure amounts to, of course, the immediate write-off of all spending on capital equipment. For this reason, a CIT that defines $F$ to be its tax base is also known as a cash-flow tax. ${ }^{67}$ It is obvious from equations (27) and (28) that consumption can now be written as

$C=W+F$.

\footnotetext{
${ }^{66}$ For simplicity, government expenditure is subsumed in the either $C$ or $I$, and exports/imports and other international income flows are ignored. These simplifications do not, however, affect the generality of the basic results under discussion.

${ }^{67}$ The disallowance of interest as a deductible expense under the cash-flow tax is to prevent the subsidization of debt-financed capital expenditures. An alternative version of the cash-flow tax would allow a deduction for interest payments, but would at the same time count net debt increase (new debt less amortization of old debt) as part of the tax base.
} 
The flat tax proposal thus encompasses a wage tax on individuals and a cash-flow tax on corporations at the same rate, resulting in an economy-wide single-rate tax on consumption. It should be noted, however, that the single-rate feature of this proposal is purely by design; there is nothing inherent in the flat tax idea that precludes the possibility of a multi-rate wage tax (although its name would then become somewhat of a misnomer).

\section{Expenditure $\operatorname{tax}^{68}$}

Like the wage tax, the expenditure tax aims to move the conventional PIT to a consumptionbased tax; unlike the wage tax, it accomplishes this goal through a different method: by allowing a deduction from total (labor and capital) income savings undertaking by individuals. Such a deduction would, by definition, result in a tax whose base comprises only consumption, as is clear from equation (27). More importantly, this way of arriving at taxing consumption is in every conceptual aspect equivalent to the wage tax, which can be demonstrated by continuing with the earlier two-period framework.

With savings being deductible under the expenditure tax, the individual's first-period budget constraint is now

$(1-\tau) \cdot(y-v)=x_{1}$

In the second period, the individual undertakes no savings, so no deduction is allowed. The tax would then be imposed on the entire amount of income derived from first-period savings plus any return earned on it. The second-period budget constraint is thus

$(1-\tau) \cdot(1+r) \cdot v=x_{2}$

It turns out that, by combining equations (30) and (31), one arrives at exactly the same lifetime budget constraint as given by equation (23). Hence, the individual would choose the same consumption path $\left(x_{1}, x_{2}\right)$ under either the expenditure tax or the wage tax.

\section{USA $\operatorname{tax}^{69}$}

Instead of replacing the conventional PIT/CIT with the individual wage tax/corporate cashflow tax combination, as proposed by the flat tax, the USA (which stands for "unlimited savings allowance") tax would replace the conventional PIT with the individual expenditure tax and replace the conventional CIT with a corporate consumption-based value-added tax (VAT). The value-added of the output of a corporation is the difference between its total sales and total purchases of (material) inputs. When these inputs include the purchase of

\footnotetext{
${ }^{68}$ The expenditure tax has a long history in economics. The most notable early exponents of the idea were Fisher and Fisher (1942) and Kaldor (1955).

${ }^{69}$ See Seidman (1997) for a detailed discussion of the USA tax.
} 
capital goods, the value-added so computed is considered consumption-based (since it no longer incorporates the value of the capital goods). By double-entry accounting principles, this consumption-based value-added is nothing other than $W+F$, or the sum of wages, interest payments, profits, and depreciation, minus expenditures on capital goods.

The similarity between the flat tax and the USA tax proposals is thus clear. The one substantive difference between them is that wages are actually taxed twice under the latter: once under the corporate VAT and again under the individual expenditure tax. Hence, the USA tax has a much larger base than the flat tax, and accordingly could meet a given revenue objective with much lower tax rates than the latter. Supporters of the USA tax would also explicitly propose a progressive expenditure tax on individuals. As noted earlier, this aspect of the USA tax can be equally accommodated by a progressive wage tax under the flat tax proposal.

\section{Discussion}

Both the flat tax and the USA tax proposals go beyond reforming the conventional PIT: each aims to remove capital income from the bases of both the conventional PIT and CIT, or, equivalently, to convert these income taxes into consumption taxes. Under each, the conventional CIT would be transformed primarily into a cash-flow tax, whose economic merits are well-known, including that of a zero marginal tax rate on corporate investment. ${ }^{70}$ Desirable as such a CIT reform may be, it is not an indispensable part of a PIT reform. Purely from the perspective of the latter reform, the conceptual significance of either the flat (wage) tax or the USA (expenditure) tax is that it effectively taxes only labor income, although each achieves this outcome using a different - though conceptually equivalent - method. The different methods do, however, entail different administrative and equity implications.

The shift to labor income as the tax base under the wage tax is direct, and thus seems administratively straightforward and easy to accomplish. ${ }^{71}$ However, its explicit exemption of capital income could be perceived by many as highly inequitable. In contrast, under the expenditure tax, the shift to labor income is indirect, and thus the appearance of inequity could be lessened. On the downside, its implementation requires the identification of changes to the net balances of all qualified savings vehicles (or, equivalently, changes to a specifically-defined measure of overall net wealth) of individuals. If the concept of net wealth is defined in a sufficiently broad manner (as would be necessary to ensure that only labor income is in fact taxed), the extent to which it would raise enforcement and compliance

\footnotetext{
${ }^{70}$ It is, of course, possible to subject investments already undertaken before the switch to the cash-flow tax to the old tax regime, in which case the average effective tax rate on investment may not be zero following the adoption of the cash-flow tax. For a good discussion of the properties of the cash-flow tax, see McLure and Zodrow (1996). A cash-flow tax may entail uncertain international tax implications, however, as regards the creditability of such a tax in foreign investors' home countries.

71 There is, however, the difficulty of separating the labor and capital income components of the self-employed. This (which does not arise with the expenditure tax) is discussed below in connection with the dual income tax.
} 
costs is still very much an uncertain matter. ${ }^{72}$ Finally, transition issues, such as the treatment of "old" wealth, or income earned from it, would need to be addressed under either tax. ${ }^{73}$

\section{B. Addressing Global Capital Mobility}

For a variety of policy and administrative reasons, schedular elements are present in the tax systems in most countries, despite their formal adherence to the global income approach to taxation. However, around the early 1990s, a group of Nordic countries (Denmark, Finland, Norway, and Sweden), concerned with high global capital mobility but faced with the need to retain high PIT rates for revenue reasons, decided explicitly to tax capital income separately from labor income. While the extent of this separation varies across individual members of the group, collectively their approach to income taxation has come to be known as the dual income tax (DIT). ${ }^{74}$

In its pure form, the DIT has the following main characteristics: ${ }^{75}$ (1) capital income includes interest, dividends, capital gains, rents, royalties (from acquired assets), and business profits; (2) labor income includes wages and salaries (including the value of imputed labor services of the self-employed - see further discussion below), pensions and social security benefits, perquisites, and royalties not classified as capital income; (3) the rate of tax on capital income is uniform (to prevent tax arbitrage) and moderate (on account of high capital mobility); and (4) the rates on labor income are progressive (for equity reasons) and generally higher than the rate on capital income (on account of low labor mobility), but not so high as to provide a strong incentive to the self-employed to disguise labor income as capital income.

In general, the income tax systems in Finland and Norway come closest to the DIT as described above, while Denmark's has strayed from it the furthest. Table 1 provides a comparative picture of the main features of the income tax systems in the four Nordic countries. Several notable aspects emerge from the comparison: (1) the separate taxation of capital income and labor income is largely achieved in Finland, Norway, and Sweden, while Denmark only manages the separate taxation of dividends; (2) the CIT rate is set at or close to the bottom PIT rate on labor income in each of the four countries; (3) taxing capital income at a uniform rate is not always achieved even in those countries that have largely

\footnotetext{
${ }^{72}$ To date, only India and Sri Lanka had briefly experimented with an expenditure tax. Hence, there has been little practical experience associated with its implementation. The PIT treatment of pension schemes in most European countries (see Chapter VII below) does inject an expenditure tax element into the PITs in these countries (as noted in Chapter IV), but it involves only a single savings vehicle.

${ }^{73}$ The issue is one of windfall gains to old wealth if the PIT is converted to a wage tax, and one of double taxation of old wealth if it is converted to an expenditure tax.

${ }^{74}$ The DIT of the Nordic countries should not be confused with the DIT of Italy, which taxes profits attributable to investments financed from qualifying new equity at a lower (19 percent) than standard (36 percent) CIT rate.

${ }^{75}$ For an informative discussion on the DIT in the Nordic countries, see Cnossen (2000).
} 
Table 1. Comparative Features of the Income Tax Systems in the Nordic Countries, 2002

\begin{tabular}{|c|c|c|c|c|}
\hline & \multicolumn{2}{|c|}{ Strong DIT features } & \multicolumn{2}{|c|}{ Weak DIT features } \\
\hline & Finland & Norway & Denmark & Sweden \\
\hline Year of reform & 1993 & 1992 & 1994 & 1991 \\
\hline CIT rate (percent) & 29 & 28 & 30 & 28 \\
\hline \multicolumn{5}{|l|}{ PIT rates (percent) } \\
\hline Wages and salaries $1 /$ & $30-59$ & $28-48$ & $33-59$ & $28-56$ \\
\hline Interest & 29 & 28 & $\begin{array}{l}\text { Aggregated with } \\
\text { wages and salaries. }\end{array}$ & 30 \\
\hline Dividends 2/ & -- & -- & $28-43$ & 30 \\
\hline Capital gains on shares & 29 & $283 /$ & $\begin{array}{l}\text { Aggregated with } \\
\text { wages and salaries } \\
\text { for short-term gains } \\
\text { ( }<3 \text { years). } 4 /\end{array}$ & 30 \\
\hline Other capital income & 29 & 28 & $\begin{array}{l}\text { Aggregated with } \\
\text { wages and salaries. }\end{array}$ & 30 \\
\hline \multicolumn{5}{|c|}{ Withholding tax rates (percent) 5/ } \\
\hline Interest & 29 & -- & -- & 30 \\
\hline Dividends & -- & -- & 28 & 30 \\
\hline Integration of PIT and CIT & Full imputation. & Full imputation. & No. & No. \\
\hline
\end{tabular}

Source: Zee (2002).

1/ Inclusive of local taxes but exclusive of social security contributions (rates shown are rounded). There could be some imprecision in the indicated ranges due to variations in local tax rates by locality.

2 / In addition to the CIT.

3/ On adjusted gains: the cost basis of shares is stepped up by new retained earnings (net of the CIT) and down by losses and distributions from previously accumulated earnings.

4/ Long-term gains are taxed as dividends, but such gains from quoted shares are tax exempt if the total holding of such shares is below a stipulated threshold.

5/ On resident individuals; on nonresidents, in general, withholding taxes on interest are nil and on dividends are governed by tax treaties. 
separated capital income from labor income: in Sweden, for example, the 30 percent rate on personal capital income is slightly higher than the CIT, and dividends are double taxed in the same way as under a classical system $;{ }^{76}$ and (4) Norway has gone so far as to eliminate the double taxation of corporate retained earnings through adjusting the cost basis of shares from which taxable capital gains are to be determined.

Under a DIT, the treatment of the self-employed is the most problematic, since its income contains both a return to capital and a remuneration for labor services. In each of the four countries, a specific procedure is used to separate these two elements. ${ }^{77}$ In Finland and Norway, a presumptive rate of return on capital is used to determine the fraction of total current-period business profits (whether withdrawn or retained) that should be taxed as capital income; ${ }^{78}$ the remaining fraction is then taxed as labor income. This approach is based on the concept that underpins the DIT: all income is classifiable as either capital or labor income. In contrast, In Denmark and Sweden (and Finland for unlisted companies), all retained profits are taxed as capital income; the presumptive splitting between capital and labor income only applies to withdrawn profits. This approach views the selfemployed/closely-held companies as if they were corporations, and confers a tax advantage (relative to wage earners) to the returns to labor services of the self-employed when such returns are retained.

A common criticism against the DIT is that the above splitting of the business profits of the self-employed is arbitrary and entails administrative complexity. ${ }^{79}$ However, these limitations do not appear to be excessively severe compared to many other arbitrary and complex administrative rules that typically exist in any tax system. On the whole, the DIT seems to be a compelling alternative to a conventional PIT in balancing efficiency and equity concerns on the one hand, and addressing global capital mobility consequences on the other. By retaining a tax on capital, albeit at a relatively moderate level, it is also a much less radical reform than a full switch from income to consumption taxation.

\section{PIT in Selected OECD Countries}

This chapter surveys some important aspects of the PIT in selected OECD countries under five regional groupings: North America, Asia and Pacific, Europe (West), Europe (East), and

\footnotetext{
${ }^{76}$ Even in Finland and Norway, where uniform taxation of capital income seems to have been achieved, there are differences in the deductibility of expenses incurred in acquiring different types of capital income, thus effectively resulting in some degree of nonuniformity.

${ }^{77}$ For details, see Hagen and Sørensen (1998).

${ }^{78}$ The presumptive rate could be applied to either gross assets (Norway) or net assets (Denmark, Finland, and Sweden). The two methods would be equivalent, of course, if the presumptive rate is the same as the actual interest rate on debt.

${ }^{79}$ Indeed, some would even regard it as the Achilles heels of the DIT. On this, as well as a good general assessment of the DIT in Nordic countries, see Sørensen (1998).
} 
Nordic. These groupings provide a comprehensive cross-sectional view of OECD countries and an interesting inter-regional contrast. ${ }^{80}$

\section{A. Revenue Developments}

As Table 2 indicates, PIT revenue has remained, on average, relatively stable over the past decade in the selected OECD countries, as a share of either GDP (about 11 percent) or total tax revenue (about 28 percent). This relative stability was broadly observed in all regional groups in terms of GDP shares, but less so in terms of total tax revenue shares.

There are large differences in the level of PIT revenue among the regional groups, with the Nordic countries having the highest (reaching almost 18 percent of GDP) and the Eastern European countries having the lowest (a little below 7 percent of GDP). North American countries' average PIT revenue level (about 12 percent of GDP) exceeded all others except the Nordic countries, while Asian and Pacific countries' is more or less on par with that of the Western European countries. The importance of the PIT as a revenue source among the country groups exhibits, however, a different pattern of relativities. Since the average total tax revenue in the North American countries is significantly below that in the Nordic countries, the former's reliance on PIT revenue (over 39 percent of total tax revenue in 2001) actually surpassed the latter's (about 36 percent). Similarly, Asian and Pacific countries' traditionally low total tax revenue levels imply that they rely much more heavily on PIT revenue than do the Western European countries (by about 6 percentage points of total tax revenue in 2001).

The distribution of the PIT revenue between the central and sub-central levels of government in most of the selected OECD countries is in the former's favor, with the Nordic countries being the sole exception, where the central government on average claimed only a 38 percent share of the total in 2000 (Table 3). Elsewhere, the central government's share ranges from over 60 percent (Eastern Europe) to over 88 percent (Asia and Pacific as well as Western Europe). In a number of countries (Australia, France, Italy, Netherlands, New Zealand, and the United Kingdom), all PIT revenue accrues to the central government.

Table 4 provides a broad picture of the revenue structure and its trend over the past decade in the same countries. The average ratio of income to consumption taxes has remained unchanged at 2.6 for these countries over the past decade, with the North American countries showing a rising trend, countered by the declining trend observed in the Asian and Pacific countries. Indeed, at 4.2 in 2001, the North American countries had the highest ratio among all the regional groups - and more than twice that of the Eastern European countries (whose ratio was slightly less than 2 ).

\footnotetext{
${ }^{80}$ See Messere (1993) for detailed survey of tax policy developments, including those related to the PIT, in OECD countries. While the quantitative information contained in that survey is now somewhat dated, its qualitative discussions remain useful (a new edition of the book updating the information is forthcoming soon).
} 
Table 2. Selected OECD Countries: PIT Revenue, 1/ 1986-2002

\begin{tabular}{|c|c|c|c|c|}
\hline \multirow{5}{*}{$\begin{array}{l}\text { North America } \\
\text { Canada }\end{array}$} & \multicolumn{3}{|c|}{ Period average } & \multirow[b]{2}{*}{$2001-2002$} \\
\hline & 1986-1990 & $1991-1995$ & $1996-2000$ & \\
\hline & \multicolumn{4}{|c|}{ (In percent of GDP) } \\
\hline & 11.6 & 11.8 & 12.5 & 11.8 \\
\hline & 13.2 & 13.7 & 13.6 & 12.5 \\
\hline United States & 10.0 & 9.8 & 11.5 & 11.2 \\
\hline Asia and Pacific & 10.4 & 9.6 & 9.2 & $\begin{array}{c}8.8 \\
8.8\end{array}$ \\
\hline Australia & 13.3 & 11.5 & 12.6 & 12.1 \\
\hline Japan & 7.2 & 6.9 & 5.4 & 5.1 \\
\hline Korea & 2.8 & 3.6 & 3.9 & 3.3 \\
\hline New Zealand & 18.3 & 16.5 & 15.0 & 14.6 \\
\hline Europe (West) & 8.9 & 9.2 & 8.7 & 9.2 \\
\hline France & 4.8 & 5.2 & 6.9 & 7.8 \\
\hline Germany & 10.5 & 10.3 & 9.3 & 9.5 \\
\hline Italy & 9.9 & 10.9 & 10.9 & 11.0 \\
\hline Netherlands & 9.4 & 10.3 & 6.5 & 6.9 \\
\hline United Kingdom & 9.9 & 9.5 & 9.8 & 10.9 \\
\hline Europe (East) & $\ldots$ & 6.2 & 6.8 & 6.9 \\
\hline Czech Republic & $\ldots$ & 4.5 & 5.2 & 5.0 \\
\hline Hungary & $\ldots$ & 6.9 & 6.9 & 7.7 \\
\hline Poland & $\ldots$ & 7.2 & 8.3 & 7.5 \\
\hline Nordic & 18.3 & 17.8 & 17.7 & 16.8 \\
\hline Denmark & 24.9 & 26.0 & 26.1 & 26.2 \\
\hline Finland & 16.8 & 17.3 & 15.3 & 14.4 \\
\hline Norway & 11.4 & 10.6 & 11.1 & 10.7 \\
\hline Sweden & 20.3 & 17.4 & 18.3 & 15.9 \\
\hline Average & 12.2 & 11.0 & 10.9 & 10.7 \\
\hline & & (In percen & $\mathrm{x}$ revenue) & \\
\hline North America & 38.0 & 37.3 & 38.6 & 38.2 \\
\hline Canada & 38.5 & 38.4 & 37.7 & 36.3 \\
\hline United States & 37.5 & 36.2 & 39.5 & 40.0 \\
\hline Asia and Pacific & 34.1 & 32.1 & 30.4 & 28.6 \\
\hline Australia & 44.9 & 40.9 & 42.3 & 39.1 \\
\hline Japan & 24.8 & 24.5 & 19.6 & 19.3 \\
\hline Korea & 16.1 & 18.2 & 17.2 & 13.5 \\
\hline New Zealand & 50.5 & 44.7 & 42.6 & 42.6 \\
\hline Europe (West) & 22.9 & 23.3 & 21.5 & 23.3 \\
\hline France & 11.2 & 11.9 & 14.6 & 17.5 \\
\hline Germany & 28.7 & 27.4 & 24.7 & 26.1 \\
\hline Italy & 26.8 & 26.3 & 25.4 & 25.6 \\
\hline Netherlands & 21.3 & 23.2 & 16.0 & 17.3 \\
\hline United Kingdom & 26.7 & 27.6 & 26.7 & 30.0 \\
\hline Europe (East) & $\ldots$ & 14.8 & 17.7 & 18.7 \\
\hline Czech Republic & $\ldots$ & 10.9 & 13.7 & 12.8 \\
\hline Hungary & $\ldots$ & 15.5 & 17.1 & 20.0 \\
\hline Poland & $\ldots$ & 18.0 & 22.2 & 23.3 \\
\hline Nordic & 38.8 & 38.2 & 36.8 & 35.0 \\
\hline Denmark & 50.6 & 53.6 & 52.1 & 53.0 \\
\hline Finland & 39.7 & 37.9 & 33.3 & 31.4 \\
\hline Norway & 26.4 & 25.9 & 26.7 & 24.5 \\
\hline Sweden & 38.5 & 35.5 & 35.3 & 31.1 \\
\hline Average & 32.1 & 28.7 & 28.1 & 27.9 \\
\hline
\end{tabular}

Source: Revenue Statistics Database (OECD).

1/ General government 
Table 3. Selected OECD Countries: PIT Revenue by Level of Government, 2000

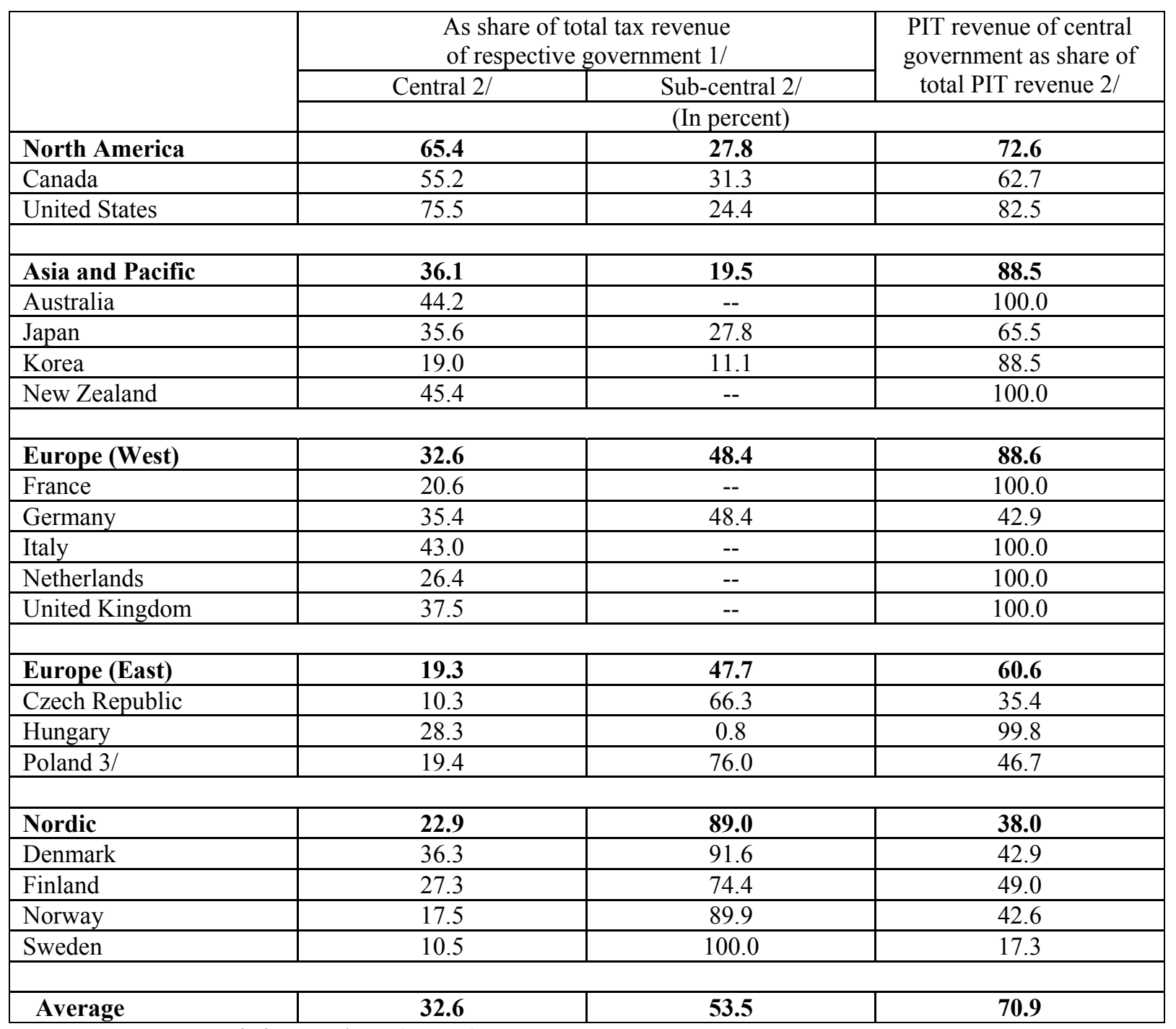

Source: Revenue Statistics Database (OECD).

1/ Excluding social security taxes.

2/ The division of PIT revenue between central and sub-central governments incorporates the part of the PIT revenue that is shared between the two.

3/ Data pertain to 1999.

4/ Data pertain to 2001. 
Table 4. Selected OECD Countries: Structure of Tax Revenue, 1/ 1986-2002

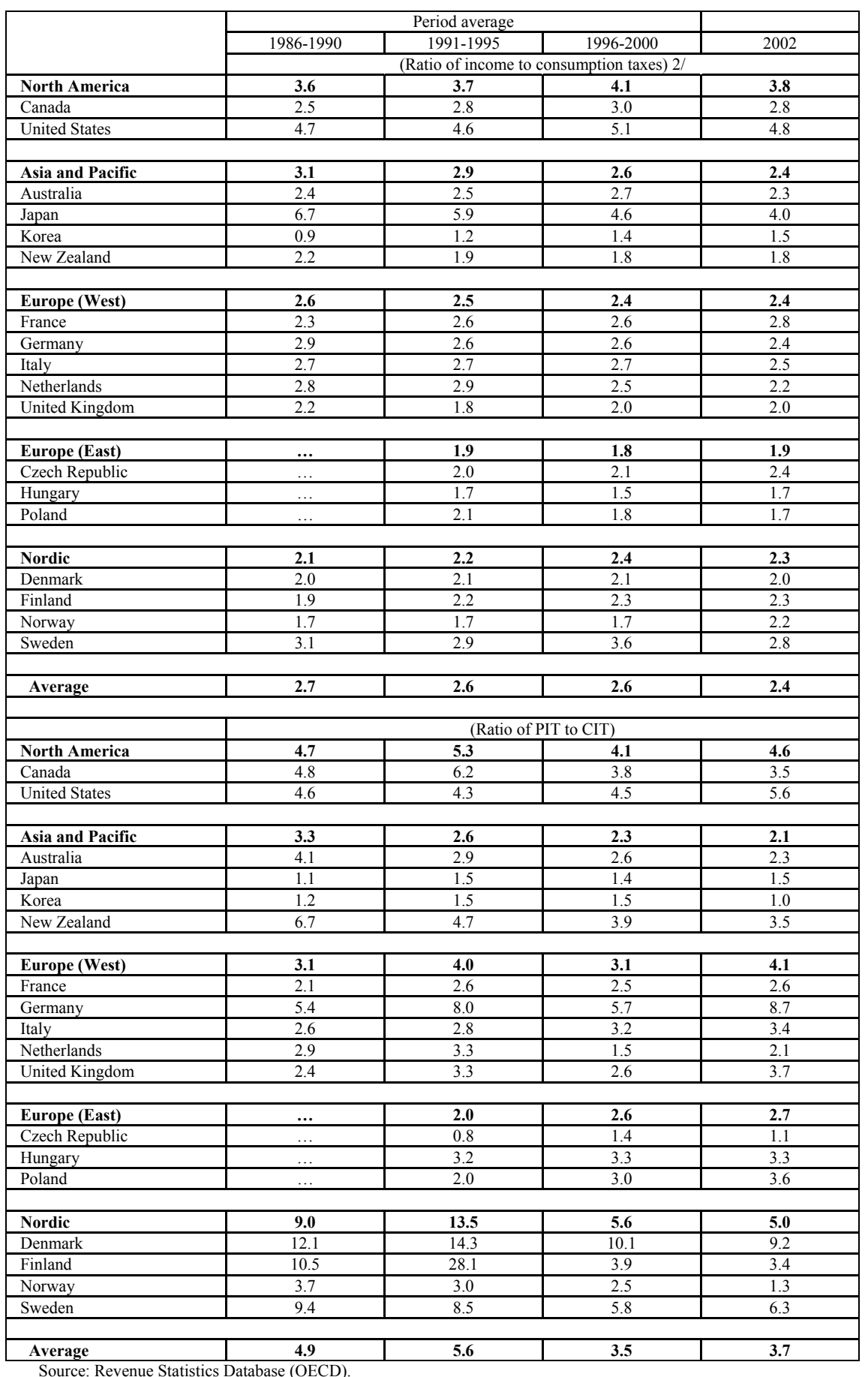

Source: Revenue Statistics Database (OECD)

$1 /$ General government.

2/ Income taxes include all direct taxes and taxes on properties; and consumption taxes include all indirect taxes. 
Much more variability was observed in the ratio of PIT to CIT revenue among the same country groups over the same period. In general, the Nordic countries historically have by far the highest ratio, followed by North America. Both of these regional groups tended, however, to converge in recent years, and were observed to have an average ratio around 4.5 in $2001-$ being exceeded in the event by Western Europe's average ratio of 5.5. The average ratios of countries in the Asia and Pacific and Eastern Europe regions were traditionally much lower by comparison-by roughly half in 2001 .

\section{B. Structural Aspects}

\section{Rate schedule and basic allowance}

Several important changes to the structure of the PIT rate schedules in the selected OECD countries between 1986 and 2002 are highlighted in Table 5. They include, at the central/federal government level, an average reduction in: (1) the maximum PIT marginal rate from about 55 percent to about 38 percent; (2) the minimum PIT marginal positive rate from about 19 percent to about 14 percent; (3) the number of PIT rates from eight to four; and (4) the excess of the maximum PIT marginal rate over the standard CIT rate from about 15 to about 8 percentage points. Furthermore, reductions in the maximum PIT marginal rate, minimum PIT marginal positive rate, and the number of PIT rates hold for all regional country groups during the period (except for the Eastern European countries, for which meaningful comparative information in 1986 did not exist). In short, the PIT rate schedules have gotten significantly flatter, lower, and simpler over the past one and a half decade.

Also of interest and significance is the change in the level of basic allowance under the PIT, which had risen, on average, from about 23 percent of per capita income to about 36 percent of per capital income for the same countries between 1986 and 2002, although this rise was not observed across all country groups (countries in the Asia and Pacific region saw a decline). As noted earlier, a higher level of basic allowance raises, all other things equal, the average progressivity of the PIT. This would tend to compensate, at least in part, any adverse equity effects of the lowering and flattening of the PIT rate schedules.

\section{Aggregate tax burden}

While PIT rates at the central/federal government level have generally come down significantly in recent years in most OECD countries, as noted above, the aggregate tax burden on personal income could well remain high, due to (1) the PITs, if any, at the subcentral government level; and (2) the SST on wages. Sub-central PITs are imposed in many OECD countries, and are especially significant in the Nordic region, where they even exceed the PITs at the central/federal level. As regards the SST, it imposes a nontrivial burden on both the employer and the employee in all OECD countries except Australia and New Zealand.

Some cross-country comparative information on the sub-central PITs and the SST for the selected OECD countries is provided in Table 6. Since the burden of the SST falls exclusively on wages, the focus is on the aggregate maximum marginal tax burden (i.e., the 
Table 5. Selected OECD Countries: PIT Rate Schedules and Basic Allowance, 1/ 1986 and 2002

\begin{tabular}{|c|c|c|c|c|c|c|c|c|c|c|}
\hline & \multicolumn{2}{|c|}{$\begin{array}{c}\text { Maximum } \\
\text { marginal rate 2/ }\end{array}$} & \multicolumn{2}{|c|}{$\begin{array}{c}\text { Minimum } \\
\text { marginal positive } \\
\text { rate } 2 /\end{array}$} & \multicolumn{2}{|c|}{$\begin{array}{c}\text { Number of } \\
\text { positive marginal } \\
\text { rates } 2 /\end{array}$} & \multicolumn{2}{|c|}{$\begin{array}{l}\text { Maximum } \\
\text { marginal rate less } \\
\text { standard CIT rate }\end{array}$} & \multicolumn{2}{|c|}{$\begin{array}{l}\text { Annual basic } \\
\text { allowance 3/ }\end{array}$} \\
\hline & 1986 & 2002 & 1986 & 2002 & 1986 & 2002 & 1986 & 2002 & 1986 & 2002 \\
\hline & \multicolumn{4}{|c|}{ (In percent) } & & & \multicolumn{2}{|c|}{ (In percent) } & \multicolumn{2}{|c|}{$\begin{array}{l}\text { (In percent of pe } \\
\text { capita income) }\end{array}$} \\
\hline North America & 43.7 & 33.8 & 23.8 & 13.0 & 8 & 5 & -0.7 & 3.2 & 13.8 & 15.7 \\
\hline Canada & 37.4 & 29.0 & 27.5 & 16.0 & 3 & 4 & -0.4 & 2.88 & 21.3 & 22.8 \\
\hline United States & 50.0 & 38.6 & 20.0 & 10.0 & 12 & 6 & -1.0 & 3.6 & 6.2 & 8.6 \\
\hline Asia and Pacific & 62.8 & 39.8 & 20.3 & 13.9 & 9 & 4 & 24.2 & 9.8 & 18.5 & 10.4 \\
\hline Australia & 60.0 & 47.0 & 25.0 & 17.0 & 5 & 4 & 14.0 & 17.0 & 25.9 & 16.5 \\
\hline Japan & 70.0 & 37.0 & 30.0 & 10.0 & 9 & 4 & 36.7 & 7.0 & 15.3 & 8.4 \\
\hline Korea & 55.0 & 36.0 & 6.0 & 9.0 & 16 & 4 & 25.0 & 9.0 & 14.4 & 8.5 \\
\hline New Zealand & 66.0 & 39.0 & 20.0 & 19.5 & 6 & 3 & 21.0 & 6.0 & $\ldots$ & 8.2 \\
\hline Europe (West) & 62.5 & 48.5 & 20.0 & 12.0 & 8 & 5 & 23.8 & 15.8 & 18.0 & 32.8 \\
\hline France & $\ldots$ & 52.75 & $\ldots$ & 7.5 & $\ldots$ & 6 & $\ldots$ & 17.32 & $\ldots$ & 17.1 \\
\hline Germany & 56.0 & 51.17 & $\ldots$ & 21.06 & $\ldots$ & $\ldots$ & 20.0 & 24.79 & 1.8 & 28.7 \\
\hline Italy & 62.0 & 46.4 & 12.0 & 18.25 & 9 & 5 & 26.0 & 9.63 & 3.9 & 30.1 \\
\hline Netherlands & 72.0 & 52.0 & 18.0 & 2.95 & 9 & 4 & 29.0 & 17.5 & 29.9 & 60.0 \\
\hline United Kingdom & 60.0 & 40.0 & 30.0 & 10.0 & 6 & 3 & 20.0 & 10.0 & 36.5 & 28.2 \\
\hline Europe (East) & $\ldots$ & 37.3 & $\ldots$ & 18.0 & $\ldots$ & 3 & $\ldots$ & 11.7 & $\ldots$ & 42.5 \\
\hline Czech Republic & $\ldots$ & 32.0 & $\ldots$ & 15.0 & $\ldots$ & 4 & $\ldots$ & 1.0 & $\ldots$ & 63.3 \\
\hline Hungary & $\ldots$ & 40.0 & $\ldots$ & 20.0 & $\ldots$ & 3 & $\ldots$ & 22.0 & $\ldots$ & 48.5 \\
\hline Poland & $\ldots$ & 40.0 & $\ldots$ & 19.0 & $\ldots$ & 3 & $\ldots$ & 12.0 & $\ldots$ & 15.7 \\
\hline Nordic & 45.2 & 23.9 & 14.9 & 12.9 & 5 & 3 & 4.5 & -4.9 & 46.7 & 70.7 \\
\hline Denmark & 39.6 & 15.0 & 14.4 & 5.5 & 3 & 3 & -10.4 & -15.0 & 74.9 & 14.0 \\
\hline Finland & 51.0 & 36.0 & 38.0 & 13.0 & 4 & 5 & 18.0 & 7.0 & 18.5 & 45.2 \\
\hline Norway & 40.0 & 19.5 & 3.0 & 13.5 & 8 & 2 & 12.2 & -8.5 & $\ldots$ & 112.8 \\
\hline Sweden & 50.0 & 25.0 & 4.0 & 20.0 & $\ldots$ & 2 & -2.0 & -3.0 & $\ldots$ & 110.7 \\
\hline Average & 54.9 & 37.6 & 19.1 & 13.7 & 8 & 4 & 14.9 & 7.8 & 22.6 & 36.0 \\
\hline
\end{tabular}

Sources: European Tax Handbook (IBFD), various issues; Taxes and Investment in Asia and the Pacific (IBFD), various issues; and Individual Taxes-A Worldwide Summary (PriceWaterhouseCoopers), various issues.

$1 /$ At the central/federal level, inclusive of surcharges.

2/ If multiple rate schedules apply, the schedule applicable to wage income for a single resident taxpayer is shown.

3 / If multiple basic allowances apply, the maximum allowance related to wage income for a single resident taxpayer is shown. The basic allowance does not include any standard deduction in lieu of itemized deductions. 
Table 6. Selected OECD Countries: Aggregate Maximum Marginal Tax Burden on Wages, 2002

\begin{tabular}{|c|c|c|c|c|c|c|}
\hline & \multicolumn{2}{|c|}{ Maximum marginal PIT rate } & \multicolumn{2}{|c|}{$\begin{array}{l}\text { Maximum marginal } \\
\text { SST rate } 1 / \\
\end{array}$} & \multicolumn{2}{|c|}{$\begin{array}{l}\text { Aggregate maximum marginal } \\
\text { tax burden }\end{array}$} \\
\hline & $\begin{array}{l}\text { Central/ } \\
\text { federal } 2 /\end{array}$ & Sub-central 3/ & Employee & Employer & $\begin{array}{c}\text { On gross } \\
\text { wages to } \\
\text { employees 4/ }\end{array}$ & $\begin{array}{l}\text { On gross labor } \\
\text { cost to } \\
\text { employers 5/ }\end{array}$ \\
\hline & \multicolumn{6}{|c|}{ (In percent) } \\
\hline North America & 33.8 & 18.0 & 6.2 & 6.2 & 52.5 & 52.9 \\
\hline Canada & 29.0 & 24.0 & 4.7 & 4.7 & 53.0 & 53.0 \\
\hline United States & 38.6 & 12.0 & 7.65 & 7.65 & 52.1 & 52.7 \\
\hline Asia and Pacific & 39.8 & 4.2 & 5.0 & 4.2 & 44.4 & 44.4 \\
\hline Australia & 47.0 & -- & $1.5^{*}$ & -- & 48.5 & 48.5 \\
\hline Japan & 37.0 & 13.0 & 14.07 & 8.675 & 50.6 & 50.6 \\
\hline Korea & 36.0 & 3.6 & 3.0 & 8.3 & 39.6 & 39.6 \\
\hline New Zealand & 39.0 & -- & 1.3 & -- & 39.0 & 39.0 \\
\hline Europe (West) & 48.5 & 0.1 & 18.9 & 23.8 & 52.4 & 57.1 \\
\hline France & 52.75 & -- & 17.4 & 33.3 & 61.6 & 68.1 \\
\hline Germany & 51.17 & -- & 20.65 & 20.65 & 51.2 & 51.2 \\
\hline Italy & 46.4 & 0.5 & $10.19^{*}$ & $34.4^{*}$ & 57.1 & 68.1 \\
\hline Netherlands & 52.0 & -- & 36.05 & 18.66 & 52.0 & 52.0 \\
\hline United Kingdom & 40.0 & -- & 10.0 & $11.8^{*}$ & 40.0 & 46.3 \\
\hline Europe (East) & 37.3 & -- & 14.6 & 27.3 & 48.7 & 58.3 \\
\hline Czech Republic & 32.0 & -- & $12.5^{*}$ & $35.0 *$ & 44.5 & 58.9 \\
\hline Hungary & 40.0 & -- & $12.5^{*}$ & $29.0 *$ & 52.5 & 63.2 \\
\hline Poland & 40.0 & -- & 18.71 & 17.88 & 49.0 & 52.8 \\
\hline Nordic & 23.9 & 27.8 & 7.5 & 21.5 & 57.5 & 64.5 \\
\hline Denmark & 15.0 & 32.6 & $9.0^{*}$ & -- & 56.6 & 56.6 \\
\hline Finland & 36.0 & 19.75 & $6.3^{*}$ & $26.55^{*}$ & 62.1 & 70.0 \\
\hline Norway & 19.5 & 28.0 & $7.8^{*}$ & $26.6^{*}$ & 55.3 & 64.7 \\
\hline Sweden & 25.0 & 31.0 & 7.0 & $32.82 *$ & 56.0 & 66.9 \\
\hline Average & 37.6 & 9.1 & 11.1 & 17.6 & 51.1 & 55.7 \\
\hline
\end{tabular}

Sources: European Tax Handbook (IBFD), various issues; Taxes and Investment in Asia and the Pacific (IBFD), various issues; and Individual Taxes-A Worldwide Summary (PriceWaterhouseCoopers), various issues.

1/ For mandatory basic old-age pensions and contributions to other social benefit schemes (e.g., unemployment insurance) if they are specified as rates on wages. In most cases, the SST is applied, in whole or in part, on wages up to a specified ceiling. An $(*)$ indicates that no such ceiling applies.

2/ From Table 5.

3/ Sub-central income taxes typically vary across locations. The rates shown are the maximum marginal (or average) rates on wages and salaries (or on aggregate income if they are aggregated with other types of income) across locations, and are inclusive of taxes at all levels of sub-central governments (to the extent such information is available).

4/ Calculated as the sum of the central/federal PIT, local PIT, and that part of the employee's SST that is not subject to a wage ceiling. The impact of the deductibility (if applicable) of the local PIT and/or SST for central/federal PIT purposes is ignored.

5/ Calculated as $(R+T) /(1+R)$, where $R$ is that part of the employer's SST that is not subject to a wage ceiling, and $T$ is the sum of the central/federal PIT, the local PIT, and that part of the employee's SST that is not subject to a wage ceiling. The impact of the deductibility (if applicable) of the local PIT and/or SST for central/federal PIT purposes is ignored 
combined burden of the central/federal PIT, the sub-central PITs, and the SST) on wages rather than other types of income. However, in calculating this aggregate tax burden, note must be taken of the SST's contribution ceilings, if any. In countries where certain components of the SST are subject to such ceilings, those concerned SST components would have no impact on the calculation of the aggregate maximum marginal tax burden.

Since the SST is almost always imposed on both the employee and the employer, the aggregate tax burden could be computed from two perspectives: on gross wages to the former and on gross labor cost to the latter. Table 6 indicates that either calculation would produce an average aggregate maximum marginal tax burden on wages that exceeds 50 percent for all countries overall, and 44 percent for every regional country group. Clearly, the aggregate tax burden on wage income remains significant in most OECD countries.

\section{Treatment of capital income}

The treatments of different forms of capital income, most notably interest, dividends, and capital gains, under the PIT are varied among the selected OECD countries, rendering generalization difficult (Table 7). Few countries follow the "global income tax" approach, preferring instead to grant capital income a variety of special tax treatments.

\section{Interest}

Less than half of the selected OECD countries tax interest income by aggregating it with other income. Even for those that do follow the aggregation practice, taxpayers may be allowed to opt for a final withholding tax (e.g., in France and New Zealand). Taxing interest income separately, through either a final withholding tax or outright exemption (as in Hungary), is a practice adopted by the majority of the countries that cuts across all regional groupings except North America.

\section{Dividends}

Except for Italy and Japan, countries that tax interest income separately also do so with respect to dividends, through either a final withholding tax or a tax whose burden could be reduced or completely eliminated by an imputation credit against the PIT for any CIT paid on the dividends. Such partial or full CIT relief is also available in countries-except Japan and the United States - where dividends are aggregated with other income for PIT purposes. Since 2002, Germany has replaced its system of imputation credits with one that requires only half of the dividends be so aggregated with other income.

\section{Capital gains}

Most of the selected OECD countries provide some forms of favorable PIT treatment of capital gains, through either separate taxation at relatively low rates or preferential treatments of certain targeted gains (e.g., gains of a long-term nature or from certain assets). Czech Republic and Hungary are notable for the absence of any special provisions in taxing capital 
Table 7. Selected OECD Countries: PIT Treatment of Capital Income, 1/ 2002

\begin{tabular}{|c|c|c|c|}
\hline & Interest & Dividends & Capital gains \\
\hline \multicolumn{4}{|l|}{ North America } \\
\hline Canada & $\begin{array}{l}\text { Generally aggregated with other } \\
\text { income. }\end{array}$ & $\begin{array}{l}\text { Generally aggregated with other } \\
\text { income. Partial CIT relief through } \\
\text { imputation: dividends are grossed } \\
\text { up by } 20 \text { percent, and imputed } \\
\text { credits are } 13.3 \text { percent of } \\
\text { grossed-up dividends. }\end{array}$ & $\begin{array}{l}\text { Generally half of the gains are } \\
\text { aggregated with other income. }\end{array}$ \\
\hline United States & $\begin{array}{l}\text { Generally aggregated with other } \\
\text { income. }\end{array}$ & $\begin{array}{l}\text { Generally aggregated with other } \\
\text { income. No CIT relief. }\end{array}$ & $\begin{array}{l}\text { Generally aggregated with other } \\
\text { income for short-term gains. } \\
\text { Long-term gains (exceeding one } \\
\text { year) are taxed at preferential } \\
\text { rates. }\end{array}$ \\
\hline \multicolumn{4}{|l|}{ Asia and Pacific } \\
\hline Australia & $\begin{array}{l}\text { Generally aggregated with other } \\
\text { income. Withholding tax rate is } \\
10 \text { percent. }\end{array}$ & $\begin{array}{l}\text { Generally aggregated with other } \\
\text { income. Complete CIT relief } \\
\text { through imputation. }\end{array}$ & $\begin{array}{l}\text { Generally aggregated with other } \\
\text { income. }\end{array}$ \\
\hline Japan & $\begin{array}{l}\text { Generally taxed separately from } \\
\text { other income at the final } \\
\text { withholding rate of } 20 \text { percent. }\end{array}$ & $\begin{array}{l}\text { Generally aggregated with other } \\
\text { income. No CIT relief. } \\
\text { Withholding tax rate is } 20 \\
\text { percent. Optional higher final } \\
\text { withholding ( } 35 \text { percent) } \\
\text { available. }\end{array}$ & $\begin{array}{l}\text { Generally taxed separately from } \\
\text { other income at various different } \\
\text { rates depending on type of asset } \\
\text { and nature of gains (i.e., short or } \\
\text { long term). }\end{array}$ \\
\hline Korea & $\begin{array}{l}\text { Generally taxed separately at the } \\
\text { final withholding rate of } 22 \\
\text { percent. }\end{array}$ & $\begin{array}{l}\text { Generally taxed separately from } \\
\text { other income at the final } \\
\text { withholding rate of } 20 \text { percent. }\end{array}$ & $\begin{array}{l}\text { Generally taxed separately from } \\
\text { other income, but at the same } \\
\text { progressive rates as those on } \\
\text { wages. }\end{array}$ \\
\hline New Zealand & $\begin{array}{l}\text { Generally aggregated with other } \\
\text { income. Withholding tax rate is } \\
19.5 \text { percent. Optional higher } \\
\text { final withholding ( } 33 \text { or } 39 \\
\text { percent) available. }\end{array}$ & $\begin{array}{l}\text { Generally aggregated with other } \\
\text { income. Complete CIT relief } \\
\text { through imputation. Withholding } \\
\text { tax rate is } 33 \text { percent on dividends } \\
\text { grossed-up by imputed credits, } \\
\text { less the imputed credits. }\end{array}$ & $\begin{array}{l}\text { Generally aggregated with other } \\
\text { income. }\end{array}$ \\
\hline \multicolumn{4}{|l|}{ Europe (West) } \\
\hline France & $\begin{array}{l}\text { Generally aggregated with other } \\
\text { income. Optional final } \\
\text { withholding at varying rates, } \\
\text { depending on the type of interest, } \\
\text { is available. }\end{array}$ & $\begin{array}{l}\text { Generally aggregated with other } \\
\text { income. Complete CIT relief } \\
\text { (except for the surtax) through } \\
\text { imputation. }\end{array}$ & $\begin{array}{l}\text { Treatment varies (partial } \\
\text { aggregation with other income or } \\
\text { taxed at reduced flat rates), } \\
\text { depending on the type of gains. }\end{array}$ \\
\hline Germany & $\begin{array}{l}\text { Generally aggregated with other } \\
\text { income. Withholding tax rates } \\
\text { range from } 26.38 \text { percent to } 36.93 \\
\text { percent, depending on the type of } \\
\text { interest. }\end{array}$ & $\begin{array}{l}\text { Generally half of the dividends } \\
\text { are aggregated with other income. } \\
\text { Withholding tax rate is } 21.1 \\
\text { percent. No CIT relief. }\end{array}$ & $\begin{array}{l}\text { Gains above certain thresholds } \\
\text { from certain assets are aggregated } \\
\text { with other income. Only half of } \\
\text { the gains from shares are } \\
\text { aggregated. }\end{array}$ \\
\hline Italy & $\begin{array}{l}\text { Generally taxed separately at the } \\
\text { final withholding rates of } 12.5 \\
\text { percent or } 27 \text { percent, depending } \\
\text { on the type of interest. }\end{array}$ & $\begin{array}{l}\text { Generally aggregated with other } \\
\text { income. Complete CIT relief } \\
\text { through imputation. }\end{array}$ & $\begin{array}{l}\text { Short-term gains are generally } \\
\text { aggregated with other income. } \\
\text { Long-term gains (exceeding } 3 \text { or } \\
5 \text { years) are taxed at reduced } \\
\text { rates. }\end{array}$ \\
\hline Netherlands & $\begin{array}{l}\text { Exempt (a } 30 \text { percent tax applies } \\
\text { on the deemed net yield of } 4 \\
\text { percent on assets). }\end{array}$ & $\begin{array}{l}\text { Exempt (a } 30 \text { percent tax applies } \\
\text { on the deemed net yield of } 4 \\
\text { percent on assets). }\end{array}$ & Generally exempt. \\
\hline United Kingdom & $\begin{array}{l}\text { Generally aggregated with other } \\
\text { income. Withholding tax rate is } \\
20 \text { percent on certain types of } \\
\text { interest. }\end{array}$ & $\begin{array}{l}\text { Generally aggregated with other } \\
\text { income. Partial CIT relief through } \\
\text { tax credit. }\end{array}$ & $\begin{array}{l}\text { Generally aggregated with other } \\
\text { income. }\end{array}$ \\
\hline
\end{tabular}


Table 7. Selected OECD Countries: PIT Treatment of Capital Income, 1/ 2002 (continued)

\begin{tabular}{|c|c|c|c|}
\hline & Interest & Dividends & Capital gains \\
\hline \multicolumn{4}{|l|}{ Europe (East) } \\
\hline Czech Republic & $\begin{array}{l}\text { Generally taxed separately at the } \\
\text { final withholding rate of } 15 \\
\text { percent. }\end{array}$ & $\begin{array}{l}\text { Generally taxed separately at the } \\
\text { final withholding rates of } 15 \\
\text { percent. No CIT relief. }\end{array}$ & $\begin{array}{l}\text { Generally aggregated with other } \\
\text { income. }\end{array}$ \\
\hline Hungary & Generally exempt. & $\begin{array}{l}\text { Generally taxed separately at the } \\
\text { final withholding rate of } 20 \\
\text { percent on a taxpayer's equity } \\
\text { share multiplied by twice the } \\
\text { prime rate of the Hungarian } \\
\text { National Bank; excess taxed at } 35 \\
\text { percent. No CIT relief. }\end{array}$ & $\begin{array}{l}\text { Generally aggregated with other } \\
\text { income. }\end{array}$ \\
\hline Poland & $\begin{array}{l}\text { Generally taxed separately at the } \\
\text { final withholding rate of } 20 \\
\text { percent. }\end{array}$ & $\begin{array}{l}\text { Generally taxed separately at the } \\
\text { final withholding rate of } 15 \\
\text { percent. No CIT relief. }\end{array}$ & $\begin{array}{l}\text { Generally aggregated with other } \\
\text { income for gains from financial } \\
\text { assets. Other gains are generally } \\
\text { taxed separately at } 10 \text { percent. }\end{array}$ \\
\hline \multicolumn{4}{|l|}{ Nordic } \\
\hline Denmark & $\begin{array}{l}\text { Generally aggregated with other } \\
\text { income. }\end{array}$ & $\begin{array}{l}\text { Generally taxed separately at the } \\
\text { final withholding rate of } 28 \\
\text { percent; the withholding is not } \\
\text { final if dividends exceed a } \\
\text { specified threshold, in which case } \\
\text { they are taxed at } 43 \text { percent. No } \\
\text { CIT relief. }\end{array}$ & $\begin{array}{l}\text { Generally aggregated with other } \\
\text { income. Long-term gains } \\
\text { (exceeding three years) from } \\
\text { shares are taxed as dividends. }\end{array}$ \\
\hline Finland & $\begin{array}{l}\text { Generally taxed separately at the } \\
\text { final withholding rate of } 29 \\
\text { percent. }\end{array}$ & $\begin{array}{l}\text { Generally taxed separately at the } \\
\text { CIT rate of } 29 \text { percent. Full CIT } \\
\text { relief through imputation. }\end{array}$ & $\begin{array}{l}\text { Generally taxed separately at } 29 \\
\text { percent. }\end{array}$ \\
\hline Norway & $\begin{array}{l}\text { Generally taxed separately at } 28 \\
\text { percent. }\end{array}$ & $\begin{array}{l}\text { Generally taxed separately at the } \\
\text { CIT rate of } 28 \text { percent. Full CIT } \\
\text { relief through imputation. }\end{array}$ & $\begin{array}{l}\text { Generally taxed separately at } 28 \\
\text { percent; taxable gains from shares } \\
\text { are adjusted for cost basis. }\end{array}$ \\
\hline Sweden & $\begin{array}{l}\text { Generally taxed separately at } 30 \\
\text { percent. }\end{array}$ & $\begin{array}{l}\text { Generally taxed separately at } 30 \\
\text { percent. No CIT relief. }\end{array}$ & $\begin{array}{l}\text { Generally taxed separately at } 30 \\
\text { percent. }\end{array}$ \\
\hline
\end{tabular}

Sources: European Tax Handbook (IBFD), various issues; Taxes and Investment in Asia and the Pacific (IBFD), various issues; and Individual Taxes - A Worldwide Summary (PriceWaterhouseCoopers), various issues.

1/ For residents. 
gains - such gains are in fact to be aggregated with other income for PIT purposes - even though interest income in both countries is given special treatment.

\section{Base issues}

Comparative information on selected important features of the PIT base - other than the treatment of capital income - is provided in Table 8, from which the following general observations can be made:

- $\quad$ The basis of worldwide taxation for residents and territorial taxation for non-residents is adopted by all the selected OECD countries.

- $\quad$ Most of the countries have adopted the individual as the unit of taxation; joint filing of husband and wife is permitted as an option in only Germany, Norway, and the United States (France follows the rather unique and complicated "household" approach).

- In those countries where sub-central PITs are imposed, only the United States allow them to be deductible against the central/federal PIT.

- $\quad$ The deductibility of interest expenditure against the PIT depends very much on its nature: it is (1) at least partially deductible in most countries if related to the mortgage of the principal residence; (2) at least partially deductible in half of the countries if related to nonbusiness investment activities (business-related interest expenses are almost invariably deductible); and (3) not deductible in most countries if related to loans for consumption.

- All countries, except New Zealand, allow at least partial deductibility of pension contributions.

- In most countries, pension income is fully taxable as ordinary income. 
Table 8. Selected OECD Countries: Aspects of the PIT Base, 1/ 2002

\begin{tabular}{|c|c|c|c|c|c|c|c|c|}
\hline & \multirow[b]{2}{*}{$\begin{array}{l}\text { Source rule } \\
\text { for } \\
\text { residents/non } \\
\text {-residents 2/ }\end{array}$} & \multirow[b]{2}{*}{ Tax unit } & \multirow[b]{2}{*}{$\begin{array}{c}\text { Sub- } \\
\text { central } \\
\text { PIT 3/ 4/ }\end{array}$} & \multicolumn{3}{|c|}{ Interest expenditure 4/ } & \multirow[b]{2}{*}{$\begin{array}{l}\text { Pension } \\
\text { contri- } \\
\text { butions 4/ }\end{array}$} & \multirow[b]{2}{*}{$\begin{array}{c}\text { Pension } \\
\text { income 5/ }\end{array}$} \\
\hline & & & & $\begin{array}{l}\text { Mortgage } \\
\text { (principal } \\
\text { residence) }\end{array}$ & $\begin{array}{c}\text { Non- } \\
\text { business } \\
\text { Invest- } \\
\text { ment }\end{array}$ & $\begin{array}{c}\text { Consump- } \\
\text { tion }\end{array}$ & & \\
\hline \multicolumn{9}{|l|}{ North America } \\
\hline Canada & $\mathrm{W} / \mathrm{T}$ & Individual. & ND & ND. & $\mathrm{D}$ & ND & $\mathrm{DL}$ & $\mathrm{T}$ \\
\hline United States & $\mathrm{W} / \mathrm{T}$ & $\begin{array}{l}\text { Individual; or } \\
\text { joint (separate } \\
\text { rate schedule). }\end{array}$ & $\mathrm{D}$ & $\mathrm{DL}$ & $\mathrm{DL}$ & ND & $\mathrm{DL}$ & $\mathrm{T}$ \\
\hline \multicolumn{9}{|l|}{ Asia and Pacific } \\
\hline Australia & $\mathrm{W} / \mathrm{T}$ & Individual. & $\ldots$ & ND & $\mathrm{ND}$ & $\mathrm{ND}$ & $\mathrm{DL}$ & $\mathrm{T}$ \\
\hline Japan & $\mathrm{W} / \mathrm{T}$ & Individual. & $\mathrm{ND}$ & $\mathrm{DL}$ & ND & ND & $\mathrm{DL}$ & RT \\
\hline Korea & $\mathrm{W} / \mathrm{T}$ & Individual. & ND & $\mathrm{DL}$ & $\mathrm{ND}$ & ND & $\mathrm{DL}$ & RT \\
\hline New Zealand & $\mathrm{W} / \mathrm{T}$ & Individual. & $\ldots$ & ND & $\mathrm{D}$ & $\mathrm{ND}$ & ND & $\mathrm{E}$ \\
\hline \multicolumn{9}{|l|}{ Europe (West) } \\
\hline France & $\mathrm{W} / \mathrm{T}$ & Household. & $\ldots$ & $\mathrm{PC}$ & $\mathrm{ND}$ & $\mathrm{ND}$ & $\mathrm{DL}$ & $\mathrm{T}$ \\
\hline Germany & $\mathrm{W} / \mathrm{T}$ & $\begin{array}{l}\text { Individual; or } \\
\text { joint (income- } \\
\text { splitting). } \\
\end{array}$ & $\cdots$ & ND & $\mathrm{D}$ & ND & $\mathrm{DL}$ & $\mathrm{T}$ \\
\hline Italy & $\mathrm{W} / \mathrm{T}$ & Individual. & ND & $\mathrm{DL}$ & $\mathrm{ND}$ & $\mathrm{ND}$ & $\mathrm{DL}$ & $\mathrm{T}$ \\
\hline Netherlands & $\mathrm{W} / \mathrm{T}$ & Individual. & $\ldots$ & $\mathrm{DL}$ & $\mathrm{ND}$ & ND & $\mathrm{D}$ & $\mathrm{T}$ \\
\hline United Kingdom & $\mathrm{W} / \mathrm{T}$ & Individual. & $\ldots$ & ND & $\mathrm{DL}$ & ND & $\mathrm{DL}$ & $\mathrm{T}$ \\
\hline \multicolumn{9}{|l|}{ Europe (East) } \\
\hline Czech Republic & $\mathrm{W} / \mathrm{T}$ & Individual. & $\ldots$ & $\mathrm{DL}$ & ND & $\mathrm{ND}$ & $\mathrm{DL}$ & $\mathrm{T}$ \\
\hline Hungary & $\mathrm{W} / \mathrm{T}$ & Individual & $\ldots$ & $\mathrm{DL}$ & $\mathrm{ND}$ & ND & $\mathrm{PC}$ & $\mathrm{E}$ \\
\hline Poland & $\mathrm{W} / \mathrm{T}$ & Individual. & $\ldots$ & $\mathrm{DL}$ & $\mathrm{ND}$ & ND & $\mathrm{DL}$ & $\mathrm{T}$ \\
\hline \multicolumn{9}{|l|}{ Nordic } \\
\hline Denmark & $\mathrm{W} / \mathrm{T}$ & Individual. & ND & $\mathrm{D}$ & $\mathrm{D}$ & $\mathrm{D}$ & $\mathrm{DL}$ & $\mathrm{T}$ \\
\hline Finland & $\mathrm{W} / \mathrm{T}$ & Individual. & ND & $\mathrm{D}$ & $\mathrm{D}$ & ND & $\mathrm{DL}$ & $\mathrm{T}$ \\
\hline Norway & $\mathrm{W} / \mathrm{T}$ & $\begin{array}{l}\text { Individual; or } \\
\text { joint (separate } \\
\text { rate schedule). }\end{array}$ & ND & $\mathrm{D}$ & $\mathrm{D}$ & $\mathrm{D}$ & $\mathrm{DL}$ & $\mathrm{T}$ \\
\hline Sweden & $\mathrm{W} / \mathrm{T}$ & Individual. & ND & $\mathrm{D}$ & $\mathrm{D}$ & $\mathrm{D}$ & $\mathrm{DL}$ & $\mathrm{T}$ \\
\hline
\end{tabular}

Sources: European Tax Handbook (IBFD), various issues; Taxes and Investment in Asia and the Pacific (IBFD), various issues; and Individual Taxes-A Worldwide Summary (PriceWaterhouseCoopers), various issues.

$1 /$ Central/federal level.

2/ $\mathrm{W}=$ world-wide; $\mathrm{T}=$ territorial.

3/ On wages and salaries, or on aggregate income when they are aggregated with other types of income

4/ $\mathrm{D}=$ deductible; $\mathrm{DL}=$ deductible with limits; $\mathrm{ND}=$ not deductible; $\mathrm{PC}=$ partial credit.

5/ T=taxable; $\mathrm{RT}=$ reduced taxation; $\mathrm{E}=$ exempt. 


\section{REFERENCES}

Atkinson, Anthony B., 1980, "Horizontal Equity and the Distribution of the Tax Burden," in The Economics of Taxation, ed. by Henry J. Aaron and Michael J. Boskin (Washington: The Brookings Institution), pp. 3-18.

Auerbach, Alan J., and Joel Slemrod, 1997, "The Economic Effects of the Tax Reform Act of 1986," Journal of Economic Literature, Vol. 35, pp. 589-632.

Blinder, Alan S., 1975, "Distribution Effects and the Aggregate Consumption Function," Journal of Political Economy, Vol. 83, pp. 447-75.

Boskin, Michael J., 1978, “Taxation, Saving, and the Rate of Interest," Journal of Political Economy, Vol. 86, pp. S3-S27.

— Couples," Journal of Public Economics, Vol. 20, pp. 281-87.

Burns, Lee, and Richard Krever, 1998, "Individual Income Tax," in Tax Law Design and Drafting, Vol. 2, ed. by Victor Thuronyi (Washington: International Monetary Fund), pp. 495-563.

Browning, Edgar K., 1995, "Effects of the Earned Income Tax Credit on Income and Welfare," National Tax Journal, Vol. 48, pp. 23-43.

Cnossen, Sijbren, 2000, "Taxing Capital Income in the Nordic Countries: A Model for the European Union?" in Taxing Capital Income in the European Union, ed. by Sijbren Cnossen (New York: Oxford University Press), pp. 180-213.

Diamond, Peter A., 1998, "Optimal Income Taxation: An Example with a U-Shaped Pattern of Optimal Marginal Tax Rates,” American Economic Review, Vol. 88, pp. 83-95.

Feldstein, Martin, 1976, "On the Theory of Tax Reform," Journal of Public Economics, Vol. 6, pp. 77-104.

Fisher, Irving, and Herbert W. Fisher, 1942, Constructive Income Taxation (New York: Harper and Brothers).

Goode, Richard, 1975, The Individual Income Tax, $2^{\text {nd }}$ edition (Washington: The Brookings Institution).

Hagen, Kåre P., and Peter B. Sørensen, 1998, “Taxation of Income from Small Businesses: Taxation Principles and Tax Reforms in the Nordic Countries," in Tax Policy in the Nordic Countries, ed. by Peter B. Sørensen (London: Macmillan Press), pp. 28-71. 
Hall, Robert E. and Alvin Rabushka, 1995, The Flat Tax, $2^{\text {nd }}$ edition (Stanford: Hoover Institution Press).

Harris, Peter A., 1996, Corporate/Shareholder Income Taxation (Amsterdam, The Netherlands: IBFD Publications).

Hausman, Jerry A., 1985, “Taxes and Labor Supply," in Handbook of Public Economics, ed. By Alan J. Auerbach and Martin Feldstein, Vol. 1 (New York: North Holland), pp. 213-63.

Hemming, Richard, and Michael J. Keen, 1983, "Single-crossing Conditions in Comparisons of Tax Progressivity," Journal of Public Economics, Vol. 20, pp. 373-380.

Kakwani, Nanak C., 1977, "Measurement of Tax Progressivity: An International Comparison," Economic Journal, Vol. 87, pp.71-80.

_, 1980, Income Inequality and Poverty (New York: Oxford University Press).

Kaldor, Nicholas, 1955, An Expenditure Tax (London: George Allen and Unwin).

Kanbur, Ravi, and Matti Tuomala, 1994, "Inherent Inequality and the Optimal Graduation of Marginal Tax Rates," Scandinavian Journal of Economics, Vol. 96, pp. 275-82.

King, John, 2004, "Securities Companies, Investment Funds, and Pension Funds," in Taxing the Financial Sector, ed. by Howell H. Zee (Washington: International Monetary Fund), pp. 32-44.

Lambert, Peter J., 2001, The Distribution and Redistribution of Income, $3^{\text {rd }}$ edition (Manchester, United Kingdom: Manchester University Press), pp. 219-36.

McLure, Charles E., Jr. and George R. Zodrow, 1996, “A Hybrid Consumption-Based Direct Tax Proposed for Bolivia," International Tax and Public Finance, Vol. 3, pp. 97112.

Messere, Ken C., 1993, Tax Policy in OECD Countries (The Netherlands: IBFD Publications).

Meyer, Bruce D., and Dan T. Rosenbaum, 2001, "Welfare, the Earned Income Tax Credit, and the Labor Supply of Single Mothers," Quarterly Journal of Economics, Vol. 116, pp. 1063-114.

Musgrave, Richard A., 1990, “Horizontal Equity, Once More,” National Tax Journal, Vol. 43, pp. 113-22.

Musgrave, Richard A., and Tun Thin, 1948, “Income Tax Progression, 1929-48," Journal of Political Economy, Vol. 56, pp. 498-514. 
Norregaard, John, 1997, "Tax Treatment of Government Bonds," Tax Notes International, Vol. 15, pp. 143-53.

Organization for Economic Cooperation and Development (OECD), 1994, Taxation and Small Businesses (Paris).

, 1999, Taxing Powers of State and Local Government (Paris).

$\longrightarrow$, 2000, Model Tax Convention on Income and on Capital (Paris).

Scholz, John K., 1996, "In-work Benefits in the United States: The Earned Income Tax Credit," Economic Journal, Vol. 106, pp. 156-69.

Seade, Jesus, 1982, “On the Sign of the Optimum Marginal Income Tax," Review of Economic Studies, Vol. 49, pp. 637-43.

Seidman, Laurence S., 1997, The USA Tax: A Progressive Consumption Tax (Cambridge: MIT Press).

Sørensen, Peter B., 1995), "Changing Views of the Corporate Income Tax," National Tax Journal, Vol. 48, pp. 279-94.

— 1998, "Recent Innovations in Nordic Tax Policy: From the Global Income Tax to the Dual Income Tax," in Tax Policy in the Nordic Countries, ed. by Peter B. Sørensen (London: Macmillan Press), pp. 1-27.

Summers, Lawrence, 1981, "Capital Taxation and Accumulation in a Life Cycle Growth Model," American Economic Review, Vol. 71, pp. 533-44.

Sunley, Emil M., 1977, "The Choice Between Deductions and Credits," National tax Journal, Vol. 30, pp. 243-7.

Tanzi, Vito, 1995, "Fiscal Federalism and Decentralization: A Review of some Efficiency and Macroeconomic Aspects," in Annual World Bank Conference on Development Economics 1995, ed. by Michael Bruno and Boris Pleskovic (Washington: The World Bank), pp. 295-316.

— OECD Countries," Banca Nazionale del Lavoro Quarterly Review, Vol. 53, pp. 3143.

Ter-Minassian, Teresa, ed., 1997, Fiscal Federalism in Theory and Practice (Washington: International Monetary Fund).

Tuomala, Matti, Optimal Income Tax and Redistribution (Oxford: Claredon Press). 
United States, 1992, Integration of the Individual and Corporate Tax Systems (Washington: Department of the Treasury).

— 1995, Earned Income Credit: Targeting to the Working Poor (Washington: Government Accounting Office).

Van der Heeden, Koenraad, 1998, "The Pay-as-You-Earn Tax on Wages," in Tax Law Design and Drafting, Vol. 2, ed. by Victor Thuronyi (Washington: International Monetary Fund), pp. 564-96.

Zee, Howell H.. 1995, “Taxation and Equity," in Tax Policy Handbook, ed. by Parthasarathi Shome (Washington: International Monetary Fund), pp. 30-4.

— 1998, "Taxation of Financial Capital in a Globalized Environment: The Role of Withholding Taxes," National Tax Journal, Vol. 51, pp. 587-99.

— 2002, "Taxing Capital Income in a Globalized World," Tax Notes International, Vol. 27, pp. 1185-211.

— 2004a, "Inequality and Optimal Redistributive Tax and Transfer Policies," Public Finance Review, Vol. 32, pp. 359-81.

— 2004b, "Innovative Financial Instruments," in Taxing the Financial Sector, ed. by Howell H. Zee (Washington: International Monetary Fund), pp. 45-59. 